THE UNIVERSITY OF CHICAGO

\title{
ELECTRONIC PROXY STATEMENT DISSEMINATION AND \\ SHAREHOLDER MONITORING
}

\author{
A DISSERTATION SUBMITTED TO \\ THE FACULTY OF THE UNIVERSITY OF CHICAGO \\ BOOTH SCHOOL OF BUSINESS \\ IN CANDIDACY FOR THE DEGREE OF \\ DOCTOR OF PHILOSOPHY
}

BY

RACHEL GEOFFROY

CHICAGO, ILLINOIS

DECEMBER 2018 
Copyright (c) 2018 by Rachel Geoffroy All Rights Reserved 


\section{TABLE OF CONTENTS}

LIST OF FIGURES . . . . . . . . . . . . . . . . . . . . . v

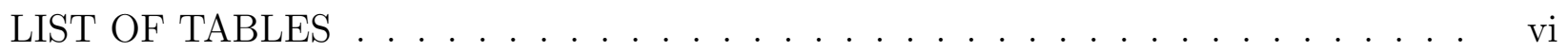

ACKNOWLEDGMENTS .................................... vii

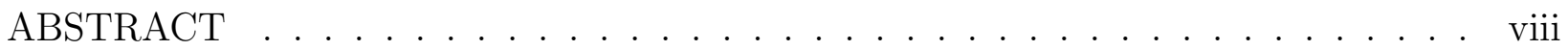

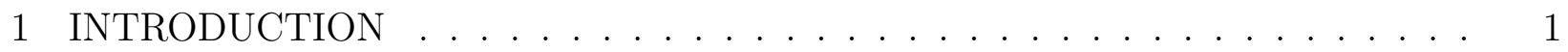

2 REGULATORY BACKGROUND . . . . . . . . . . . . . . . . . 10

2.1 SEC E-proxy . . . . . . . . . . . . . . . . . . . . . . . . . . . . . . . . . . . . . . . .

2.2 Canadian notice and access . . . . . . . . . . . . . . 13

3 PREDICTIONS . . . . . . . . . . . . . . . . . . . . . . 15

3.1 Information Costs . . . . . . . . . . . . . . . . . . 16

3.2 Signaling . . . . . . . . . . . . . . . . . . . . . . . . . . . . . . . . . . . . . . . . . . . . . .

3.3 Participation and Voting . . . . . . . . . . . . . . . . 19

3.4 Strategic Dissemination . . . . . . . . . . . . . . . . . . . . . . . 20

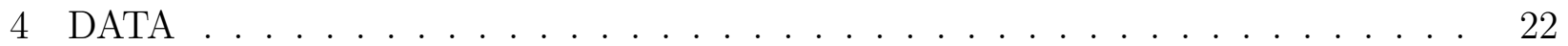

4.1 Measuring Participation . . . . . . . . . . . . . . . . . 22

4.2 Measuring Treatment . . . . . . . . . . . . . . . . . . . . 24

4.3 Sample and Controls . . . . . . . . . . . . . . . . . . . . 26

4.4 Canadian Data . . . . . . . . . . . . . . . . . . . . . . . . . . . . . . . . . . . . . . .

4.4.1 Measuring Treatment . . . . . . . . . . . . . . . 27

5 RESEARCH DESIGN AND RESULTS . . . . . . . . . . . . . . . . . . . 29

5.1 Effect of Electronic Dissemination on Participation . . . . . . . . . . . 29

5.1 .1 Design $1 \ldots \ldots \ldots \ldots$. . . . . . . . . . . . . . . 29

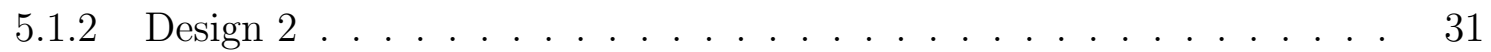

5.1.3 Estimates on Participation Effect . . . . . . . . . . . . . . . . . 32

5.1 .4 Canadian Setting . . . . . . . . . . . . . . . . . . . . . . . . . . . . . . . . 32

5.2 Institutional Ownership Splits . . . . . . . . . . . . . . . . 33

5.3 Electronic Dissemination and Voting Results . . . . . . . . . . . . . . . . . 34

5.3 .1 Director Elections . . . . . . . . . . . . . . 36

5.3.2 Canadian Notice and Access and Outcomes . . . . . . . . . . . . . 37

5.4 Strategic Dissemination . . . . . . . . . . . . . . . . . . 38

5.5 Descriptive Information about Dissemination Switches and Stratification . . 40

5.6 Robustness and Limitations . . . . . . . . . . . . . . . . . . . . . . . . . . . 42

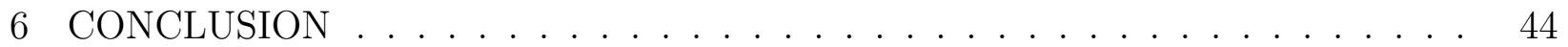

REFERENCES . . . . . . . . . . . . . . . . . . . . 46 


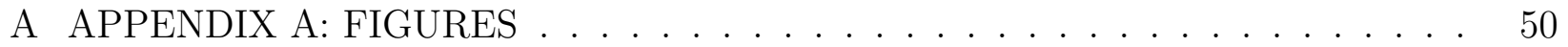

B APPENDIX B: TABLES . . . . . . . . . . . . . . . . . . . 60 


\section{LIST OF FIGURES}

A.1 Figure 1: E-proxy Before and After . . . . . . . . . . . . . . . . 51

A.2 Figure 2: Notice . . . . . . . . . . . . . . . . . . . . . . . . . 52

A.3 Figure 3: Ownership Structure . . . . . . . . . . . . . . . . . . . 53

A.4 Figure 4: Routine versus Non-routine . . . . . . . . . . . . . . . . . . . 54

A.5 Figure 5: Broadridge . . . . . . . . . . . . . . . . . . 57

A.6 Figure 6: Standard Canadian Disclosure in Proxy Information Circular . . . . . 59 


\section{LIST OF TABLES}

B.1 Variable Definitions . . . . . . . . . . . . . . . . . . . . 61

B.2 Table 1: Summary Statistics . . . . . . . . . . . . . . . . . 64

B.3 Table 2: Total Non-Participation . . . . . . . . . . . . . . . . . . . . . 68

B.4 Table 3: Effect on Participation . . . . . . . . . . . . . . . . 70

B.5 Table 4: Institutional Ownership . . . . . . . . . . . . . . . . . . . . . . 74

B.6 Table 5: Voting Outcomes . . . . . . . . . . . . . . . . . 76

B.7 Table 6: Strategic Dissemination . . . . . . . . . . . . . . . . . 84

B.8 Table 7: Switching and Stratification . . . . . . . . . . . . . . 86

B.9 Table 8: Robustness . . . . . . . . . . . . . . . . . . . . . . 87 


\section{ACKNOWLEDGMENTS}

Special thanks goes to my dissertation committee for their invaluable feedback: Phil Berger (chair), Hans Christensen, Mark Maffett, and Abbie Smith. I would also like to thank the following: John Barrios, Jonathan Bonham, Matthias Breuer, Jung Ho Choi, John Gallemore, Anya Kleymenova, Heemin Lee; workshop participants at the University of Chicago, University of California Los Angeles, Tulane University, Florida International University, The Ohio State University, and the Securities and Exchange Commissions Department of Economic and Risk Analysis; and many others, including the Canadian Securities Administrators and various industry professionals, for their helpful suggestions and comments. I would like to recognize financial support from the Booth School of Business Accounting Research Center

and the Fisher College of Business. I would also like to thank my parents for supporting me through this entire process. All errors are my own. 


\begin{abstract}
This paper examines how the means of disseminating proxy statements affects shareholder monitoring. I exploit the staggered implementation of a regulatory change that allows firms to switch from postal mail to electronic distribution. I estimate that electronic dissemination reduces total voting participation by about 1\%-2.2\%. Under the plausible assumption that all beneficial shareholder non-participation is from retail investors, my results imply retail investor voting non-participation increases by approximately $7 \%-17 \%$ when electronic distribution is used. The reduction in retail investor participation shifts voting outcomes in favor of managements recommendations for routine votes and shifts voting outcomes against management recommendation for non-routine votes. Consistent with management understanding the importance of dissemination channels, I further show management strategically uses its discretion over the choice of the proxy statement dissemination channel to affect voting.
\end{abstract}




\section{CHAPTER 1 \\ INTRODUCTION}

It is an intriguing question as to whether our own electronic delivery rules for proxy materials may have unintentionally depressed retail investor participation. . . . I believe that a retrospective review of our electronic proxy rules is long overdue.

-Michale Piwowar, SEC commissioner, Feb. 19, 2015

Retail investors are an economically important investor group, and increasing their participation in corporate governance decisions has recently been a key regulatory concern. Participating in shareholder voting is one way that investors monitor management. Participation is generally low, which can exacerbate agency conflicts. This paper examines the effects of electronic dissemination of proxy statements on monitoring of company management by retail investors. It also provides evidence that management makes strategic decisions regarding dissemination of proxy statements, consistent with dissemination having corporate governance effects.

Although the number of retail investors holding stocks directly, rather than through a pension, hedge fund, or mutual fund, is decreasing, these retail investors still constitute a large portion of total investment. Somewhere between 50 million and 56 million Americans hold individual stocks (Bricker et al., 2014). Institutional ownership has grown tremendously, but retail investors still hold an estimated $23 \%-38 \%^{1}$ of the equity market directly (Kaiser, Snider, \& Lewis, 2013). For comparison, mutual funds own about 20\%, and pensions about 16\% (Kaiser et al., 2013). However, retail participation in shareholder meetings is fairly low. Industry has estimated that only about $30 \%$ of retail investors participate in shareholder

1. There is a large dissention in the economics literature on how to measure retail investor ownership, particularly because IRS, Federal Reserve survey and SEC data provide different estimates. The Federal Reserve's "Survey of Consumer Finances" estimated that $17.9 \%$ of American families owner stocks directly in 2007. 
elections for stock they own (Broadridge, 2015). I find that average individual investor participation between 2011 and 2016 is $46 \%$, which is lower than the $57 \%$ turnout rate for the 2012 U.S. presidential election (Cvijanovic et al., 2017).

The value of investor participation in shareholder meetings has been a long-standing question in the literature touching on fundamental trade-offs of principle-agent relationships. Shareholder meetings allow investors to monitor management (Appel et al., 2016) and to express their objective function to management (Hart and Zingales, 2017). However, investors have less knowledge than management about the firm and the best ways of optimizing value (Wohlstetter, 1993; Lipton and Rosenblum, 1991). This issue could be exacerbated by retail investors, who would include some of the least sophisticated investors.

Nonetheless, regulators have stated many reasons for why retail investor participation is important. They value retail investor participation because participation is a major right of shareholders, which they have a duty to protect. The U.S. Securities and Exchange Commission (SEC) also sees the proxy process as a vital means by which shareholders and company leadership communicate with one another and wants to create rules that would increase informed participation to empower shareholders (Commissioner Luis A. Aguilar, February 19, 2015). Lawyers argue that retail investor participation is fundamental to the legitimacy of the capital markets and beneficial to aggregate welfare (Solomon, 2017). The agency has thus increased educational outreach to try to promote informed participation as a way to level the playing field between retail and institutional investors and increase trust in the capital markets.

Not only is the value of retail participation unknown, but the factors that drive retail investor participation are mostly unexplored. Previous research has shown total shareholder meeting participation is correlated with institutional ownership (Brickley et al., 1988), which is unsurprising, because institutional owners now typically have a fiduciary responsibility to vote. Theory states that retail participation should be influenced by divergence in preferences between institutional and retail investors (Cvijanovic et al., 2017). Whether dissemination 
method is a factor in retail participation is a contentious issue amongst regulators. In most developed countries, the government regulates the dissemination of documents related to shareholder meetings, but regulators do not have clear measurements of the costs and benefits of electronic dissemination.

The main regulatory shock in my paper is the passage of e-proxy regulation. Before eproxy, companies were required to disseminate proxy documents through postal mail. With e-proxy, the SEC required companies to choose between two proxy statement distribution systems, the full-access system (full access) and the notice and access system (notice). Under the full access system, the company must post proxy materials on their website while continuing to send physical copies of the proxy documents. Under the notice system, investors receive an email with a link to the proxy materials. The introduction of the change was staggered, based on the size of the company providing the information. Large accelerated filers had an effective date of January 1, 2008, whereas companies with public floats of less than $\$ 700$ million had an effective date of January 1, 2009. This staggered implementation provides variation to test the effect on voting patterns.

Before implementation, the response to the regulation was largely positive. A handful of firms adopted early, because using e-proxy reduced printing and mailing costs. In 2015, physical copies cost on average $\$ 6.93$ more than electronic dissemination per investor per meeting (Broadridge, 2016). Because the regulation increased options for dissemination, many thought it would decrease information costs, and thus embraced the new rule. However, opinion quickly turned after implementation. Former SEC Chairman Mary Schapiro gave a speech in 2009 asking for feedback, given the amount of complaints from investors and companies after adoption.

I present two theories for how e-proxy could decrease participation. The first theory is that it increases information costs for the retail investors, making participation in shareholder meetings more costly. If these costs are high enough, investors might disengage. Assuming retail investors have a more elastic participation function than institutional investors, changes 
to proxy information costs should mainly work to enfranchise or disenfranchise them. The second theory is that retail investors treat the form of dissemination as a signaling device, assuming e-proxy communications are less important because they are cheaper, and that companies send physical copies of documents for important or close elections for which participation might affect the outcome.

I use two approaches to examine the effects of the e-proxy regulation. The first focuses on the change in participation for non-routine votes of adopting firms in the post period, because participation should only change for non-routine votes. Brokers can vote for nonparticipating beneficial investors during routine votes, but not non-routine votes. Thus, for routine votes, a change in retail investor participation should result in no change in observable participation, while a change in institutional participation should result in a change in observable participation. With non-routine votes, however, the broker must report its retail clients non-participation as a non-vote, and changes in participation of both retail and institutional investors are reflected in observed participation. Within-firm routine versus non-routine votes are the main variation. I also estimate a difference-in-differences specification, where I solely look at non-routine votes to focus on how a firms investor participation for non-routine votes decreases after the firm changes dissemination methods. In the United States, firms are not required to disclose their method of dissemination. Therefore, I use firm filings to infer which firms use full-disclosure versus notice dissemination methods.

I find that e-proxy led to approximately a $1 \%-2.2 \%$ decrease in total shareholder participation. On average, $13.5 \%$ of shares are not voted in my sample, due to the lack of retail investor participation. Therefore, the decrease represents an $7 \%-17 \%$ decrease in retail investor participation given estimates of retail investor ownership and participation.

I then examine if any change occurs in voting patterns for routine votes. I use a modified version of my second difference-in-differences research design, and this time I look at the routine votes rather than the non-routine votes. Bethel and Gillian (2002) and Akyol, Raff, and Verwijmeren (2017) hypothesize that brokers have an agency conflict, leading to them 
almost always voting for management recommendations, even when proxy advisors caution against doing so. Brokers, unlike mutual funds, do not disclose which votes they made relative to the votes the actual retail shareholders made, so enforcing a breach of fiduciary duty is almost impossible. Concerns about these agency costs were one of the reasons that Dodd-Frank restricted the types of votes that could be classified as routine. I find that as companies switch dissemination methods, and presumably monitor power transfers to brokers, the percentage of the vote that agrees with managements recommendation increases. As a falsification test, I show a similar result does not arise when I look at the non-routine votes.

Additionally, this paper provides evidence that management strategically invests in dissemination. Although the primary reason for using electronic dissemination is to save money for the firm, when a strategic or close vote takes place, management becomes more sensitive to participation of retail investors and increases spending on dissemination of proxy materials by using the more expensive physical dissemination. This shows that management is aware of how dissemination methods can affect the level of monitoring and makes dissemination choices while weighing the cost of dissemination against the benefits of increased retail investor participation. Participation might be important to management if the company is close to quorum requirements, or if it believes retail investors might be more in agreement with management than institutional investors. I study this post-Dodd-Frank, when the increase in votes in agreement for routine issues found in previous tests would not be relevant, and I show that managements voluntary use of electronic dissemination has a negative association with special contests and votes that fail.

I also study implementation of Canadas similar notice and access regulation in February 2013. Introducing the Canadian setting into my research design helps me deal with potential measurement error because, unlike in the U.S. setting, I do not have to make any inferences regarding how the information is disseminated. Furthermore, it increases the generalizability of my results and investigates whether the Canadian changes designed to encourage partici- 
pation worked. Unlike companies in the United States, companies in Canada must disclose information about the dissemination of proxy materials and are subject to different corporate governance regulations based on where they are registered. Canadian companies registered at the federal level have a much more burdensome approval process. By contrast, as of February 2013, firms registered in the major provinces adopt voluntarily.

The Canadian regulation created requirements for notice dissemination very similar to requirements in the United States, with only three major design differences. The first is that companies must disclose the dissemination method, which helps address measurement issues. The second is that, unlike in the US, where large firms adopted first, in Canada, smaller firms registered at the province rather than the federal level could adopt first. This helps give additional generalizability to my results because I am no longer relying on a single size cut-off. The third is that the notice must be designed so that investors will not need to go to the site with the proxy materials to vote, because a paper ballot was still sent to investors unaccompanied by a proxy document. Thus, the mechanism is even more unambiguously the change in information dissemination rather than ease of voting options.

One finding from the Canadian setting is that mixed dissemination strategies, with the exception of differentiation between beneficial and registered investors, are fairly uncommon. Less than one percent of Canadian firms use more than one dissemination method for beneficial investors, and usually different methods are based on geographic location. This goes against the only survey evidence on firms dissemination choices, where the National Investor Relations Institute (NIRI) reported that $42 \%$ of U.S. firms in their sample used a mixed strategy (NIRI, 2008). Firms using mixed strategies, where some beneficial investors received e-proxy and others did not, would imply that my finding underestimates the true effect of e-proxy. Using different dissemination strategies for registered and beneficial investors is more common, but this form of strategic dissemination would not change my interpretation of findings.

I also find that the rates of dissemination switch in the Canadian setting are similar to the 
U.S., where $4.9 \%$ of companies that use e-proxy will switch back to physical dissemination for some portion, if not all, of the investor base, compared to $4.4 \%$ in the United States. The Canadian setting, with its high-quality data, confirms that the rate of notice and access use for special elections is lower than the rate of notice and access use for annual meetings. That phenomenon can be found in the average notice and access rates for the different types of meetings and in the notice and access determinants regression with firm fixed effects.

It becomes even more apparent that there is a selection effect when looking at the relationship between notice and access and the percent of the vote in agreement with management recommendation. When looking at the variation between firms for the same time of vote, there is a correlation between voting outcome and use of notice and access, driven by registered investors, the group of investors that investor relations has the most information about and access to. However, when using firm fixed effects to look at the variation within a firm and controlling for signs predictive of a more controversial vote, the relationship between voting outcomes and use of notice and access becomes negative. Use of notice and access for the entire investor base is associated with a $1.1 \%$ decrease in votes in agreement with management recommendation. This is consistent with the dissemination switching that I see in the sample where firms switch dissemination methods when the vote is close enough or the issue important enough to justify the expense for a very modest increase that would only be economically significant for a small fraction of votes. The votes for which a $1.1 \%$ change in the vote would be economically significant are disproportionally likely to be important votes for the future of the firm.

Lastly, I find a decrease in voter participation in the Canadian setting, particularly when the firm uses notice and access for beneficial investors. I estimate the effect of notice and access for beneficial investors to be around $12 \%$ and for the entire investor base to be around 14\%. This is larger than the effect that I found in the U.S., and it is unclear if that is because of the differences in investor bases between the two countries, or the higher quality of the data. 
This paper contributes to the literature by addressing how the dissemination of information affects corporate governance. Few papers have examined the information-distribution channel. Additionally, the proxy statement setting has useful characteristics for measuring distribution effects. The proxy statement has fewer substitutes for information related to shareholder voting than for earnings information. Thus, a clear and regulated notification of when the information is posted and how to find it is a discrete shock to search costs. There should be no anticipatory effect besides possible early adoption. Anticipation of a new information channel does not change search costs, and therefore should not affect participation before the channel is adopted. Finally, we can observe concrete and measurable decisions in the near aftermath.

By exploring retail investor participation, this paper also plumbs the costs and benefits of different dissemination methods, which is a recent area of focus in the accounting literature. Bushee et al. (2010), for example, show the importance of media coverage, an external voluntary disseminator of accounting information. Blankespoor et al. (2014) examine voluntary dissemination, firm use of Twitter, and increased firm liquidity. Christensen et al. (2017) look at a regulatory dissemination change, addressing how including known information in an accounting document makes the information more impactful. My research examines both the regulated and voluntary decisions surrounding dissemination of corporate governance documents, creating the first tie between the dissemination method and monitoring and corporate governance.

The previous literature has shown that close votes are discontinuously more likely to result in agreement with managements recommendation, which implies that management is able to affect the vote (Babenko et al. 2018). The literature has explained this result by showing multiple channels through which management can strategically affect voting outcomes, such as changing the record dates, selectively withdrawing or adjourning a proposal to be voted on at a later date, acquiring more shares for their personal portfolios (Fos and Jiang 2015), asking the SEC to exclude shareholder proposals (Soltes et al. 2017), lobbying specific 
shareholders to influence their votes (Cvijanovic et al. 2016), and timing special meetings around good news (Babenko et al. 2018). Managerial decisions that can affect the voting outcome where the proposed channel is participation include whether to employ the services of a professional proxy solicitation firm (Young et al. 1993) or when to call for polls closing and how to reconcile discrepancies in vote counts (Kahan and Rock 2008). My research contributes to this literature by providing yet another channel through which management can try to strategically affect the vote. 


\section{CHAPTER 2}

\section{REGULATORY BACKGROUND}

This paper examines two regulatory changes: the U.S. e-proxy regulation and the Canadian notice and access regulation.

\subsection{SEC E-proxy}

The SECs e-proxy regulation introduced electronic dissemination of proxy materials. Eproxy companies had previously been required to disseminate proxy materials physically in the mail. The SEC allowed firms to choose between two new dissemination methods: the notice method and the full access method. In both, public companies had to make their proxy statements and annual reports available online (on a website other than EDGAR) to provide investors with more options to receive information. Additionally, companies were required to send a notice with the web address when the statements were posted online, and intermediaries were required to pass the notice to all beneficial shareholders. With the notice method, dissemination of the notice via email was sufficient. With the full access method, the notice was simply added as part of the proxy document. Notices for how to find the proxy materials online could also be posted separately on EDGAR as DEFA14A or as part of the proxy document, DEF 14A, depending on the dissemination method chosen.

E-proxy had a staggered introduction, which allows for a cleaner identification of the effects of electronic dissemination. On December 8, 2005, the SEC first proposed e-proxy. The earliest voluntary adoption of this portion of the regulation was allowed on July 1, 2007. Although most large firms had the proxy documents on their companys website before the legal requirement, they were restricted from sending the notice form before July 1, 2007. Large accelerated filers were required to adopt an e-proxy dissemination method by January 1, 2008. All other public companies had an effective date of January 1, 2009.

The SEC allowed some stipulations to protect investors. Investors could contact the 
company or their broker regarding their individual preference for receiving e-mail or physical copies of proxy statements and annual reports. The default was electronic dissemination for the notice method, and physical dissemination for the full access method. During this time, if retail investors did not send in proxy forms ten days before the shareholder meeting, brokers could consider them as non-participating. Requests for a change in the dissemination method from the default could lead investors to miss the ten-day cutoff. However, most investors did not deviate from the default, with most companies reporting only around $1 \%$ of investors requesting a return to physical mail if the company chose to use notice dissemination. Lastly, the regulation required protection of the shareholders anonymity for both dissemination methods.

E-proxy only changed the dissemination method; all else stayed the same. The SEC gave strong guidance on how the notification was to be formatted and specified what information was required and permitted. Nothing about the contents or the formatting of the proxy document changed with the rule change. The regulation did not require online proxy voting, although it was permitted. Alternatively, the company could provide a printable proxy form or display a toll-free phone number with the online proxy material. The SEC made this change to help reduce information-dissemination costs for firms. Because this regulation was designed to help cut costs, firms are unlikely to try to strategically avoid the regulation. For example, firms are unlikely to try to manipulate their classification as large accelerated filers.

However, before implementation, the SEC did receive several comments that the new procedures could lead to a change in investor participation in proxy voting. The comments were split on whether this change would lead to an increase or decrease in investor participation, with more firms commenting that they believed it would increase participation. The SEC noted, in Release No. 34-55146, that more people sent in letters predicting an increase in participation than letters predicting a decrease. This response led to the SEC initially having low expectations of negative changes in participation. 
After implementation, comments from high-level SEC employees suggest the agency started hearing complaints that e-proxy led to lower participation and that the SEC had no idea what was driving this decrease or how to verify these stories. Previous chairman, Mary Jo White, asked anyone with more information about e-proxy to contact the SEC. In a speech in 2008, SEC commissioner Paul Atkins said the distribution change might have led to an approximately $70 \%$ decrease in retail participation, which is a substantial enough drop to impact corporate governance. ${ }^{1}$ Because of the SECs fear of falling participation, the agency had created a website and hotline by 2010 to help confused investors understand e-proxy. ${ }^{2}$

Statements like this one rely heavily on information from Broadridge (formally ADP Shareholder Services), the company that has a majority market share in proxy-voting logistics, and, to my knowledge, they have not been verified. Broadridge sent a letter to the SEC in 2009, after the regulation took effect, and the companys representatives met with the SEC to discuss the regulation. Appendix A, Figure 5, presents some of Broadridges disclosures to the SEC regarding e-proxy. Broadridge has stated it noticed lower participation rates among beneficial shareholders from firms that chose the notice and access system, but said it did not have time-series data to determine why participation might have declined (Broadridge, 2009). The Institutional Shareholder Services (ISS) data I use includes time-series data, which allows me to assess whether the firms that chose the notice and access system had lower participation before the law was enacted, and to try to determine what predicts the choice of distribution system. However, unlike Broadridge, I cannot see retail participation for routine items.

Because electronic dissemination is not specific to proxy dissemination, the SECs impres-sion of the cost-benefit trade-off resulting from e-proxy has continuing policy ramifications.

1. He gave estimates in which the number of retail accounts voting had over a $70 \%$ drop and the number of retail shares voting had a $48 \%$ drop. Broadridge estimates that around a third of all retail investors voted before the rule change. If those figures are correct, this reaction caused between a $3.5 \%$ and $9 \%$ drop in total shareholder voting.

2. The website can still be found at https://www.sec.gov/spotlight/proxymatters/e-proxy.shtml. 
The SEC has continued to push back electronic dissemination of mutual fund prospectuses. Commission members, such as Kara Stein, have said numerous times in interviews with The Wall Street Journal that they are concerned the benefits of any switch to default digital delivery, in the form of reduced printing and distribution fees, are outweighed by potential harms such as reduced investor access to critical fund reports. At this time, I remain concerned about interfering with investor choice without clearer evidence that it will not do more harm than good (Ackerman \& OConner, 2016). When Canada changed its dissemination system, the provinces adopted something similar to the e-proxy with a few useful distinctions.

\subsection{Canadian notice and access}

On February 11, 2013, Canada launched its notice and access regulation from an amendment to Part 9 of NI 51-102 Continuous Disclosure Obligation and NI 54-101 Communication with Beneficial Owners of Securities of a Reporting Issue. As with the U.S. version, Canadian firms could voluntarily choose to use the notice and access system. Whereas the provincial corporate governance statutes had no references to notice and access, the Canada Business Corporate Act specifically required it. This difference created a two-tiered system in which firms registered at the provincial level could easily adopt notice and access, whereas firms registered at the federal level needed to get approval. Unlike in the U.S., smaller firms could therefore adopt before larger firms in Canada.

Furthermore, because the Canadian regulators were aware of the political outcry after the U.S. e-proxy regulation, they intentionally changed two things. First, Canadian firms were required to post a detailed description of proxy-dissemination practices 20 days before the meeting. This disclosure allows me to determine how an investor should expect to receive proxy documents in Canada more easily than in the U.S., especially because some firms use a mixture of notice and access and full dissemination. This difference is beneficial to my research design because it makes identification of treatment more reliable. Second, Canadian 
regulators changed the design of the notice in a fundamental way. Their U.S. counterparts had wanted to ensure retail investors had read the proxy documents before voting, and thus required investors to go to the website with the proxy documents to access the voting instructions. 3 In Canada, physical proxy cards with postage can be distributed without sending out a printed proxy document with it, and investors do not need to go through the proxy document to vote online.

Another difference between the U.S. and Canada when looking at voting issues is the treatment of broker non-votes. The distinction between routine and non-routine votes and existence of broker non-votes is a U.S. phenomenon. Some cross-listed firms with large U.S. ownership will report broker non-votes, but that is the exception rather than the rule. There are other factors that limit the sample in Canada instead of broker voting. For example, when estimating the participation effect in Canada, I exclude all votes determined by show of hands, which is still a valid method of counting votes for some Canadian firms. However, there is no routine/non-routine distinction except for cross-listed firms.

Although no study has been made of the Canadian regulation, ${ }^{4}$ Broadridge has again provided statistics. These statistics show that, unlike in the United States, retail investor participation in Canada potentially increased somewhat with notice and access adoption. 5 This finding suggests the United States could reform proxy dissemination in simple ways to increase participation without giving up notice and access or electronic dissemination.

3. Although U.S. regulators did allow companies more flexibility with the design of the notices starting in 2010, they did maintain the principle that the design should promote reading the proxy document before voting.

4. As of my conversation with an Ontario Securities official on March 17, 2017, no internal review of the regulation has occurred.

5. They show a $7 \%$ increase in notice and access participation in comparison to the traditional dissemination. 


\section{CHAPTER 3 PREDICTIONS}

This paper is one of the first to investigate what drives participation in shareholder meetings. Therefore, I want to start from what we know about participation in political elections. As with the political setting, an investors decision to vote can be represented as a maximization function whereby increased value of the firm from monitoring and psychological factors increases utility from voting. Most economic models for political voting are based on Riker and Ordeshooks A Theory of the Calculus of voting, that gives the following model for voting:

$$
V=P B+D C
$$

$\mathrm{V}$ is the latent utility from voting. $\mathrm{P}$ is the probability that the voters vote will decide the vote. $\mathrm{B}$ is the expected monetary benefit of the voters preferred outcome, making PB the combined expected benefit of voting (Riker \& Ordeshook, 1968).

In the traditional models, D represents a civic duty to vote, but in my model, D is the psychological benefit from exercising ones right to vote. As owners of the firm who have trusted the company to an agent, investors do not have a duty to vote, as citizens do for political voting. Investors do have the right to vote and may reap psychological benefits from exercising that right, such as feeling a greater connection to the company. Fama and French (2007) provide evidence that investors receive non-monetary benefits from ownership; therefore, to extrapolate that some investors receive non-monetary benefits from voting is not unusual.

Lastly, $\mathrm{C}$ is the cost of voting. Information costs, such as the opportunity costs of finding and understanding the proxy documents, decrease participation. I assume $\mathrm{C}$ is a fixed cost all investors must pay and is heterogeneous to investors, but an increase in ownership will not

increase C. Essentially, C is the one-time commitment of time needed to read a proxy and 
become informed. Some investors will have a higher premium on their time, but ownership should have no causal relation with C, only B. C might be dependent on sophistication.

The regulation should affect the model in two ways, which I will explain in the following sections. The major predictions from the two are similar, but the policy implications differ.

\subsection{Information Costs}

The first way of viewing this regulation is as a shock to C. If electronic dissemination increases (decreases) information costs, I expect participation to decrease (increase). Electronic dissemination might increase information costs for retail investors for several reasons. Electronic dissemination might affect the ease with which investors can find and access the proxy document, or it might change the ease of processing the information within the proxy document.

Psychologists and educational specialists have studied the effects of electronic versus paper documents on information processing. Muter et al. (1982) find that reading speed is slower and comprehension higher for paper books than for the same material on a computer. Switchenko (1984), by contrast, finds no effect when the text formatting perfectly matches, and the difficulty of the passage is lowered. Subsequent literature finds such factors as lighting, the readers posture, and spacing between lines often reduces or eliminates differences between the media (Oborne \& Holton, 1988). Firms disseminating complicated text cannot control the lighting or the readers posture. Randomized trials show students reading printed texts score significantly better on reading comprehension tests than those reading text off computer screens (Mangen et al., 2013).

We can reasonably assume a shock to $\mathrm{C}$ would have a greater effect on retail investors than on institutional investors. Retail investors are frequently less sophisticated, which might change the degree to which $\mathrm{C}$ changes when dissemination changes. Furthermore, many institutional investors use standardized information platforms, with additional information from proxy advisors, which would help insulate them from dissemination changes. Therefore, 
I would expect any participation change to be driven by retail investors, which leads to my first hypothesis.

H1: If e-proxy represents an increase (decrease) in fixed costs, participation, particularly from retail investors, will decrease (increase).

Under the information-costs model, a change in participation related to e-proxy implies a transfer of wealth among investors. Whereas the firm was previously paying some amount X to disseminate this information to unsophisticated investors, it now saves $\mathrm{X}$ and distributes that savings through earnings based on ownership. Unsophisticated investors, who are more likely to be small minority investors, end up either paying the shock to $\mathrm{C}$ or becoming disenfranchised. Thus, the new regulation would essentially move the burden of costs from large investors to small investors.

\subsection{Signaling}

An alternative explanation is that e-proxy creates the opportunity to signal the expected benefits of a vote. A signaling model implies B is not the same for all votes. Assume two types of votes exist: important and unimportant. The voting benefits associated with these two types are $B \in\left\{B_{H}, B_{L}\right\}$ with $B_{H}>B_{L}$. Previously, B was unobservable to investors until they incurred $\mathrm{C}$, but was privately known by the management, who, before e-proxy, could not credibly communicate B before the investors incurred C. Investors make the decision to participate based on a pooled mean benefit. BH and BL occur with probability $\mathrm{q}$ and 1-q, respectively. $P B_{H}+D>C$, but $P B_{L}+D<C$. If $P\left(q B_{H}+(1-q) B_{L}\right)>C$, being able to distinguish between $\mathrm{BH}$ and $\mathrm{BL}$ will lead to an average decrease in participation.

Fewer retail investors might participate when information is disseminated electronically, because they take this form of dissemination as a signal that a vote is not important. Printing and postage makes physical dissemination costlier, potentially allowing dissemination to serve as a costly signal. Estimates from Broadridge suggest electronic dissemination of proxy materials saves the United States over $\$ 500$ million per year, and other estimates show notice 
and access saves about $\$ 350$ million per year (Broadridge, 2015). ${ }^{1}$ Statements from various companies suggest they save around $10 \% 15 \%$ of their investor relations budget by switching to the notice method (Jones, 2008). Firms can justify the cost of important votes for which modest increases in participation could have large implications for the firm or management. For unimportant votes, this spending could be interpreted as investor relations departments wasting money.

Although I am calling this signaling, the model would have to differ slightly from the traditional Spence (1973) signaling model, which looked at education. The Spence (1973) model has one universal benefit function, wage, and two cost functions for education, depending on the type of employee. Single crossing of the cost functions means it is optimal for the two different types of employees with their two different cost functions to choose different education levels given a single benefit for a given level of education. My model contains only one cost function for all types, but the two types have different benefit functions. Voters condition participation on the dissemination method if managers with two different types of proposals, which have two different benefits from inducing participation, choose different means of dissemination. This is equivalent to investors setting their participation function based on the means of dissemination, because the net cost of the means of dissemination for an unimportant proposal is different than for an important proposal.

If a decrease in participation stems from the signaling explanation, retail investors are making more efficient uses of their time. Before, they could not differentiate between important and unimportant votes until after they had become informed on the vote. At that point, it was rational to vote. Now, able to differentiate, retail investors can better allocate their time. This interpretation differs from the one stemming from the information-costs model.

1. http://www.broadridge.com/news-events/press-releases/Broadridge-Reports-Annual-Proxy-SeasonStatistics.html.

http://media.broadridge.com/documents/Broadridge-Distribution-and-Voting-Trends-2015.pdf. A main difference between the two is that Broadridge does not classify institutional investors use of electronic dissemination as notice and access, because it sells separate electronic platforms for dissemination to these investors. 
Because my paper will not be able to disentangle which of these two models is driving my findings, the policy interpretation of my findings is somewhat open-ended.

Disentangling the two theories might be possible. If the signaling causes the participation decrease, Canadian reforms should not make the situation better but, instead, even worse, because the Canadian reforms make it even easier to determine how much of an investment the company has made in dissemination. In the United States, investors can ask for physical copies, and improvements to the design of the notices in the United States have been made since 2010, so the decrease in participation might weaken over time if it is caused by information-cost increases.

\subsection{Participation and Voting}

Non-routine does not necessarily imply importance, though a strong correlation exists. Nonroutine votes are votes the New York Stock Exchange has declared brokers cannot vote when retail investors have failed to submit voting instructions. In Figure 4, I discuss what is considered routine and non-routine. This classification difference creates different expectations of what will happen to the vote when participation decreases.

For non-routine matters, the broker must give a separate non-vote for the beneficial shareholders, which are retail investors or insiders. Because most retail investors own shares in street name, most of them are beneficial shareholders. Therefore, for non-routine issues, if retail investors are not participating, we would expect the number of these non-votes to increase.

Bethel and Gillian (2002) provide evidence that, whereas some brokers used the recommendation of proxy advisors to determine how to vote the uninstructed shares, many simply vote for the management recommendation (Bethel \& Gillan, 2002). They find, for example, that routine stock-option-plan proposals receive more votes in agreement with management than non-routine stock-option plan proposals, even when controlling for ISSs recommendation. These findings comport with much of the anecdotal evidence from activists and 
journalists.

The argument for why brokerages do this is rooted in agency conflicts. Especially if the brokerage is not an owner in its own right, it has no incentive to become informed. Doing so would be costly, and the broker would not receive economic benefits from the monitoring. Unlike mutual funds, brokers have no voting reporting requirement, making it difficult to hold brokers accountable for breaches in fiduciary duty related to proxy voting. By contrast, by voting with management, brokers might be able to increase connections with management, which could bring in more commissions for the brokerage. This leads to my second hypothesis.

H2: If adoption of e-proxy leads to a decrease (increase) in participation, an increase (decrease) in votes in alignment with management recommendations for routine votes will occur.

\subsection{Strategic Dissemination}

Assuming management is aware of the relationship between electronic dissemination and participation, managers will want to use dissemination to strategically influence the vote. In line with the prior hypotheses, management has no incentive to spend money to increase votes for routine votes that tend to be less important and for which brokers will likely vote in favor of their recommendations. For non-routine votes, when brokers cannot vote in favor of their recommendations, management has the incentive to increase retail investor participation if retail investors are more aligned with their interests than institutional investors. Alternatively, these votes tend to be more important and contentious, and so management might want to increase participation simply to have a more representative consensus from the shareholders. I use three variables to measure the likelihood of having important and contentious non-routine votes. The first is the type of meeting. Special meetings and proxy contests are called specifically because important or contentious non-routine items have arisen that voters need to consider. The second is a vote ex-post failing. Lastly, I look at 
whether the vote received less than $70 \%$ support and management recommended investors vote For. This leads to my third hypothesis.

H3: Management will invest more in dissemination for non-routine votes that management sees as important or contentious. 


\section{CHAPTER 4 \\ DATA}

\subsection{Measuring Participation}

In order to measure the effect on participation, I first construct a measure of shareholder participation. I use voting data from ISS (formerly RiskMetrics), which has compiled the voting records from U.S. companies 10-K, 10-Q, and 8-K filings for the Russell 3000 firms. I define participation as Votes For + Votes Against + Votes Abstain + Votes Withheld (a classification of votes within ISS from before 2006, which lumps Votes Against and Votes Abstain

together), divided by the total number of shares outstanding. ISS reports participation at the meeting item level because participation will vary between items in a meeting. Meeting items with total votes cast exceeding the total number of shares outstanding are excluded from the regression. Meeting items with no reported participation are also excluded.

Historically, true participation could be observed for only a fraction of the total companies. Before 2010, brokers could vote on behalf of retail investors on routine issues if retail investors did not vote. Brokers did not need to disclose which of the votes retail investors cast and which votes brokers cast for them. Therefore, seeing actual participation by retail investors is difficult with routine votes, which were more prevalent before 2010. Full retail participation can be seen for non-routine votes; however, those are more likely to be complex issues, and more active attempts are often made to increase participation in meetings with many non-routine votes.

In 2010, Dodd-Frank changed the definition of non-routine votes. Section 957 of DoddFrank required that NYSE Rule 452 be changed to include more items as non-routine. Since the change in 2010, almost every firm has at least one non-routine voting item. The full definition of routine and non-routine votes before and after Dodd-Frank can be found in Figure 4. In Section 5, I describe how I partition the sample either before or after Dodd-Frank. 
To interpret e-proxys effects on participation, I estimate total non-participation as a percentage of outstanding shares. ${ }^{1}$ The regression for total non-participation can be found in Table 2 Panel A. I use the difference in participation between routine and non-routine votes to represent the amount of beneficial non-participation as a percentage of outstanding shares. The regression shows a $13.5 \%$ average, which I use for interpreting the results of my participation tests. I have also calculated yearly regressions on the difference between routine and non-routine votes with meeting fixed effects. Estimates resulting from the use of this method are very similar to estimates of participation from taking the average broker non-votes divided by outstanding shares for non-routine votes during a calendar year.

One issue with any other previous estimate is that they could never estimate nonparticipation for the entire U.S. market; all previous estimates were for a small sample. In Panel B, I estimate the yearly averages post Dodd-Frank, where I can now give the average of non-participation for the entire Russell 3000. I use Thompson Reuters Data to subtract institutional and insider ownership to provide the estimate of individual investor participation (retail and insiders). In Panel C, I show this estimate partitioned by size of total asset quantiles. For the total sample, individual participation is $46 \%$. Participation is highest for the largest firms $(59.7 \%)$, and lowest with the middle quantile $(32.5 \%)$. This is higher than the number that SEC officials usually cite in speeches, policy documents, and testimony to Congress, which is based off reports from Broadridge. ${ }^{2}$ Broadridge does not typically provide much information about the construction of its estimate; however, they do mention removing all institutional ownership and do not mention removing insider partici-

1. Two papers about the NYSE policy regarding the definition of routine and non-routine votes reported estimates of broker non-votes. Akol et al. (2016) estimated broker non-votes for fiscal 2009 of roughly $12 \%$, which is consistent with my calculation of $12.1 \%$ for the same time frame. Bethel and Gillan (2002) estimated broker non-votes as between 11\%-13.6\% for 1997 from a sample of 320 votes from firms larger than the general population.

2. For example, when discussing the policy objectives for his tenure as chairman of the SEC, Jay Clayton used a Broadridge estimate to justify a major overhaul of the proxy voting system. He said: In the 2017 proxy season, retail shareholders beneficially-owned $30 \%$ of the shares in U.S. public companies; however, only $29 \%$ of those shares voted. This may be a signal that our proxy process is too cumbersome for retail investors and needs updating. (Nov. 8, 2017) 
pation. Theoretically, Broadridge and I should be measuring the same construct, although they might be reporting in percentage of investors, while I am reporting it in percentage of shares. To my knowledge, I am the first academic to try to construct this variable. ${ }^{3}$

With all my tests of participation, I rely on public data on participation as reported in a $10-\mathrm{Q}$ or $8-\mathrm{K}$. Companies are more likely to have errors in the participation data if there is more short selling (Kahan and Rock, 2008). ${ }^{4}$ Short selling makes record keeping determining voting rights harder. Therefore, I present my data segmented by the amount of short positions at the end of the month prior to the meeting date. I use COMPUSTATs short positions data, and then group firms into quintiles. As can be seen in Panel D, the mean participation rate is much lower for the firms in the top quintile of short selling than the bottom quintiles. The degree to which that can be attributed to improper disclosure rather than differences in the firms or the investor base cannot be determined from this level of analysis.

\subsection{Measuring Treatment}

Next, I construct two measures of electronic dissemination. The first, which I call regulation, is based off the e-proxy regulation. Companies with a public float of more than $\$ 700$ million, classified as large accelerated filers, were required to allow investors the option to receive their proxy material and annual statements in the mail or electronically. I hand-collected

3. Cvijanovic et al. (Sept. 2017) claims to be the first researchers to estimate U.S. corporate election participation. They estimate that there is $73 \%$ turnout for discretionary voting, which includes pensions and hedge funds, because they claim that SEC Final Rule IA-2106 is not practically enforced for those institutions. However, such institutions typically have at least a $95 \%$ participation rate, where non-participation is often caused by unusual circumstances, such as a sale of the shares between the record date and the meeting, because they still have a fiduciary obligation and can be legally liable for non-participation. Therefore, I have no issue removing all institutional ownership to obtain a measure of participation more relevant to my setting and to a set of policy concerns.

4. Most brokerages pay for over-vote protective services after Deutsche Bank Securities, UBS Securities, Credit Suisse Securities, and Goldman Sachs Execution and Clearing were censured and fined by the NYSE for violating NYSE Rule 342 by failing to reasonably supervise proxy-processing operations and new best practices were devised (see NYSE Press Releases from June 13, 2006 and Feb 15, 2006). However, there are votes in my sample during the period that would have been compromised by the poor bookkeeping of these brokerages. I tried to remove votes with over-voting from my sample. 
the public float from 10-K filings for 2007 and 2008 to determine whether a firm would be required to adopt the SEC e-proxy and verified the results with Audit Analytics.

I identify adoption of e-proxy by the inclusion of Availability of Proxy Materials in either the definite proxy document (DEF 14A) or an additional definite proxy document $(\mathrm{DEFA} 14 \mathrm{~A})^{5}$. The full access method requires the company to include in the physically distributed copy a page informing investors of the new website location of the proxy materials. The emails used in the notice and access dissemination allowed by e-proxy are one of the many types of disclosures that fall under the DEFA14A category. Other types of disclosures include social media posts about the shareholder meeting, PowerPoint slide presentations from the shareholder meeting, and letters to large investors related to shareholder meeting items. The appearance of the notification in a DEFA14A shows that the company created a separate email notification and is at least partially using the notice-dissemination method.

Not all companies that adopt e-proxy file a DEFA14A, which could lead to noise in my measure of treatment. Broadridge claims that at least $40 \%$ of all shareholder meetings use notice and access, and the percentage among larger firms is even greater. However, in Table 6, I find only around 31\% use notice and access. The discrepancy ultimately comes from the legal counsels of non-DEFA14A filing firms. The courts have given materiality rules to $\S 240.14 \mathrm{a}-6$ (b) following the ruling in TSC Industries, Inc v. Northway, Inc, 426 U.S. 438 (1976); in order to prosecute, the rule requires a substantial likelihood that a reasonable stockholder would consider information important in deciding how to vote on a matter. Application of materiality varies widely between companies, leading to highly divergent disclosure policies regarding any kind of additional proxy material. If I assume the missing DEFA14As are due to the respective legal counsel not considering the notice material, I would be concerned that the posting of a DEFA14A might simply reflect the legal counsel revising

5. According to the Federal Regulation allowing e-proxy, $\S 240.14 a-16(h)(2)(i)$, The registrant must file a form of the Notice of Internet Availability of Proxy Material with the Commission pursuant to §240.14a-6(b). $\S 240.14 a-6$ (b) requires all other soliciting material, besides the definite proxy statement, to be filed with the commission, which is why the DEFA14A for additional proxy materials was created. 
materiality rather than the firm changing its practice. The total number of DEFA14As does seem to increase around contentious elections. Instead, I find that companies that previously filed notices as DEFA14As stop around contentious elections, which is consistent with strategic action but not consistent with my findings being driven by materiality.

The issues with identifying a firms dissemination method in the United States are alleviated in Canada. In Canada, companies must disclose before all shareholder meetings how they will be disseminating proxy materials, as an additional line in a highly enforced document. Canadian firms also need to explain their criteria for determining use of notice and access if they selectively use notice and access for only certain parts of their investor base. I refer to criteria to determine which portion of the investor base will use notice and access as stratification criteria. In Canada, most reported stratification criteria fall under three types. The first type is whether the investor is a registered or beneficial shareholder. The second type is the physical location of the shareholder. The last type is the number of shares held by the shareholder. Because few incentives to misreport the companys dissemination practices to regulators exist, these data should have minimal measurement noise.

\subsection{Sample and Controls}

My sample extends from 20052015. I exclude companies that Compustat reports as nonU.S. firms, because most foreign filers are not subject to Rule 14(a) for my main tests. Institutional ownership data comes from Thompson Reuters $13 \mathrm{~F}$ database, using the total institutional ownership as a percentage of the outstanding shares variable. Control variables for the director elections voting outcomes test come from ISS Governance data. More information about the construction of controls can be found in Appendix B. Table 1 provides the descriptive statistics for all variables. 


\subsection{Canadian Data}

In the Canadian tests, I construct participation and voting outcomes from Global ISS data that starts in 2013, plus additional voting data provided to me by the Canadian Securities Administrators compiling public voting data starting in 2010. Because the Canadian securities market is much smaller than the U.S. securities market, and because they adopted later, I will have a smaller sample with the Canadian setting. There is one issue that greatly decreases my sample size, and that is missing outstanding shares information in the ISS data. I construct participation in Canada very similarly to the U.S., and therefore, I use ISSs outstanding shares as the denominator in my participation fraction in both settings. In the US, ISS has very few missing observations for that variable; however, ISSs Canadian data is missing that data for a large number of their observations. For other tests besides the participation test, I treat votes for+votes against+ votes abstaining as the number of shares outstanding to increase sample size. Those observations are dropped when I estimate the participation effect.

I do not distiguish for the Canadian data whether the firm is a TSX, TSX-V, or CSE issuer, so my research cannot be used to make statements about any particular exchange. The fact that I am using ISS data may mean that my results may not be balance between

all Canadian exchanges. I was not able to parse the forms of all the data the Canadians provided, which means that my sample is less than the full universe of Canadian firms actively trading during the years of my sample. Furthermore, most of my test require more than one year of data from a single firm, which further restricts the sample and can lead to ungeneralizable results.

\subsubsection{Measuring Treatment}

Treatment will be constructed based on firm disclosures of dissemination methods in the Notice of the Meeting and Record Date form that must be filed at least 20 days before a 
shareholder meeting and that was also provided to me by the Canadian Securities Administrators. According to my agreement with the Canadian Securities Administrators, I can provide only aggregate-level statistics on all data that they have provided.

In the Notice of Meeting and Record Date form, firms answer if they will use notice and access for registered investors, if they will use notice and access for beneficial investors, and if they have stratification criteria (and if so, what it is). Because of the detail in the data, I construct several treatment variables. Beneficial Investor Notice and Access indicates if the firm responded yes to the question on if the firm used notice and access for beneficial investors. Registered Investor Notice and Access indicates if the firm responded yes to the question on if the firm used notice and access for registered investors. Any Notice and Access indicates if the firm responded yes to either of those questions. Lastly, Notice and Access is equal to 2 if the firm disclosed that they were using notice and access, the Canadian version of e-proxy, for all investors, equal to 1 for some subset of investors, and 0 if they used full access. 


\section{CHAPTER 5}

\section{RESEARCH DESIGN AND RESULTS}

In my analyses, I first identify the effect that electronic dissemination of proxy materials had on retail investor participation and voting outcomes. Then, I provide evidence that management is switching dissemination methods during important elections where management might want to increase participation.

\subsection{Effect of Electronic Dissemination on Participation}

In this section, I assess the effect that adoption of electronic dissemination had on retail investor participation. I use two empirical designs to identify the effect. The first, Design 1 , relies on variation between routine and non-routine votes within a single meeting. The second, Design 2, examines just the non-routine issues and relies on the variation in adoption time between firms.

\subsubsection{Design 1}

First, I use a triple difference (DDD) design in which I examine participation changes for nonroutine votes in the treatment group during the post period. Participation will vary within a meeting for every vote, as investors may choose not to vote at all on a particular issue. Routine votes would not show much of a participation change if retail investor participation patterns changed, because most retail investors own shares beneficially, and the institutional brokers would perfectly offset any change in participation from beneficial retail investors. Therefore, I use them as a control group, thereby controlling for any shock that might affect beneficial and registered shareholders participation equally. Non-routine votes by firms not

in the treatment group will also serve as a control. My model, suppressing year, firm, and 
voting item subscripts, is:

$$
\begin{aligned}
\text { Participation }=\alpha & +\beta_{1} \text { Regulation or DEFA*non }- \text { routine } \\
& + \text { Controls }+ \text { Meeting } F E+N o n-\text { routine } * \text { Year } F E_{F}+\epsilon
\end{aligned}
$$

The dependent variable is participation. The variable of interest is either Regulation*nonroutine, my measure of treatment based on which firms were subject to the e-proxy regulation interacted with an indicator variable that equals one when the vote is non-routine, or $D E F{ }^{*}$ non-routine, my measure of treatment based on observation of a DEFA14A filing of a notice interacted with an indicator variable that equals one when the vote is non-routine. Thus, the coefficient estimate $\beta_{1}$ will be positive if the regulation increased participation or negative if it decreased participation. I include meeting fixed effects to control for firm and time varying characteristics. I include meeting-level fixed effects, because multiple meetings are held per year, and meeting fixed effects subsume firm*year fixed effects. I include year*non-routine fixed effects to control for time trends in the retail participation. I cluster observations at the firm level.

Because little empirical evidence of what drives participation in shareholder meetings is available, I first use my model to determine the controls for the regression. In the model, the major source of omitted-variable bias would have to come from a simultaneous shock to $\mathrm{D}$, which in this setting is psychological benefits retail investors receive for exercising their right to vote. Most variables the political science field has associated with D are unobservable in this setting. I use both my fixed effects structure and several controls to deal with shocks to D. In talking to corporate governance consultants tied to Broadridge and PricewaterhouseCoopers, I found they focused on whether the topic of the vote was likely to inspire investors loyalty to the firm. Because they typically use the description of the vote, such as whether it was a merger vote or a compensation vote, to determine their expectation of retail investor loyalty, I control for several different types of votes. The contentiousness of the vote might also be a factor that is associated with the importance an investor might 
place on exercising their right; therefore, I control for the closeness of the voting result.

I also use the literature on voting outcomes and the criteria for treatment to determine controls. Cai, Gerner, and Walkling (2009) find director meeting attendance and ISS recommendations had the biggest economic impact on shareholder votes for directors. Unfortunately, I do not have ISS recommendations; therefore, I include a variable to interact earnings per share with non-routine votes. Because firm size drives the variation, I add two controls to obtain interactive effects based on the logged total assets and logged market value of the company.

\subsubsection{Design 2}

One potential concern of Design 1 is that the changes in non-routine votes over time, particularly due to Dodd-Frank, might be influencing the results. Design 2 addresses this concern by limiting the sample to include only non-routine votes from before Dodd-Frank changed NYSE Rule 452. Restricting both the years and the type of vote significantly decreases the sample size. I use a standard difference-in-differences model. My model for Design 2, suppressing year, firm, and voting item subscripts, is:

$$
\text { Participation }=\alpha+\beta_{1} \text { Regulation or DEFA+Controls }+ \text { Year }_{F E}+\text { Firm }_{F E}+\epsilon
$$

The dependent variable is still participation. The variable of interest is Regulation or $D E F A$, my two measures of e-proxy adoption. I include year fixed effects to control for time trends in participation. The year fixed effects and controlling for Delta Earnings should control for the recession. I include firm fixed effects to control for time-invariant characteristics of the company investor-base and participation. The concern with this regression is that, because it relies on changes in the time of adoption, I might not be able to sufficiently control

for the differences in other time-variant firm characteristics not related to the e-proxy regu- 
lation. However, Design 1 addresses that concern because it uses within meeting variation allowing the firm within the same time period to be its own control.

\subsubsection{Estimates on Participation Effect}

The estimates of the effect on participation can be found in Table 3. Column 1 shows a statistically significant decrease of around 2.2\%. Given the estimates from Table 2, I can interpret this as a $16.3 \%$ increase in non-participation. For Design 1, I cluster the standard errors by firm, although in non-tabulated results, I find this result is robust to industry or firm and year clustering. Because the dependent variable is a fraction out of 1 , we can interpret the coefficient as a percentage decrease in total shareholder participation. Column 2 estimates the effect using the second research design. The estimate in Column 2 is economically similar to the result in Column 1, although the statistical significance has decreased even given the clustering change to meeting level cluster to adjust for the decrease in degrees of freedom.

Columns 3 and 4 show the results using the DEFA measure. I find a negative correlation, suggesting around a $2.2 \%$ decrease in the total participation effect using Design 2 and $1 \%$ using Design 1. Results for both columns are robust to firm and industry clustering. Ideally, the DEFA measure would be stronger than the regulation measure, because I have more confidence that the firms are actually using e-proxy. Because I know my measure of DEFA is underreporting e-proxy usage, it is hard to disentangle whether measurement error in DEFA or an omitted-variable bias in Design 1 is driving the discrepancy in the estimates. This is why including the Canadian data is valuable.

\subsubsection{Canadian Setting}

Then, I estimated the effect of notice and access in Canada in Table 3 Panel B. Unlike in the United States, brokerages in Canada do not vote unvoted shares. My model for the effect of Canadian notice and access on participation, suppressing year, firm, and voting 
item subscripts, is:

$$
\begin{aligned}
\text { Participation } & =\alpha+\beta_{1} \text { Notice and Access } \\
& + \text { Controls }+ \text { Year } F E+\text { Firm }_{F E}+\epsilon
\end{aligned}
$$

The dependent variable remains participation. The variables of interest all capture aspects of firms disclosed use of the notice and access method of dissemination, allowed through the Canadian version of e-proxy, for at least some subsection of the investor base. Panel B reports the estimates of notice and access effect. Column 1 estimates the effect of using notice and access for registered investors on participation. The effect is an insignificant decrease in participation of $2 \%$. Registered Investor Notice and Access should have the smallest effect, because most registered investors are institutional, sophisticated, or highly invested in the company. Columns 2 and 3 show an estimated decrease in participation of around $12.6 \%$ for the effect of using notice and access for beneficial investors. In Columns 4 and 5, I estimate equation 3 using the comprehensive Notice and Access variable. The results indicate that using notice and access for the entire investor base would lead to a $14.8 \%$ decrease in participation. Average participation in my sample is $52 \%$, and average participation is $55 \%$, including firms that could not be matched with Compustat data.

\subsection{Institutional Ownership Splits}

To assess whether firms with higher retail ownership are driving the results, I partition the sample from Table 3 into high and low institutional investor groups. If little or no retail ownership is present, we should see little to no impact on participation from a dissemination shock that primarily affects retail shareholders. I proxy for a subset of firms, where p, the probability that the retail investor might be influential, is zero if institutional owners vote as a block. If the probability of institutional investors disagreeing is small, the average benefit should not be above cost. When $\mathrm{p}$ is sufficiently small, a shock to $\mathrm{C}$ would have little effect on participation, because voting leads to almost no monetary benefit. 
I define high institutional ownership as firms with more than $66 \%$ institutional ownership, because that percentage would be enough to ensure that institutional ownership alone could completely decide a vote if institutional owners had complete agreement. Although many companies vote along a simple majority, many companies have supermajority requirements for important votes. Using a $66 \%$ threshold would help identify firms that could theoretically decide the vote with only institutional voting, even in the case of a two-thirds supermajority requirement.

Table 4 shows the results of this split. Columns 1 and 2 estimate the effect of electronic dissemination on participation using the first empirical design and the regulation measurement with low and high institutional ownership, respectively. Columns 4 and 5 estimate the effect on participation with the DEFA14A measurement and with low and high institutional ownership, respectively. Columns 3 and 6 have the results from the chi-squared test of statistical difference between the coefficients for the high and low institutional ownership firms. The chi-squared test of statistical difference reports that firms with lower institutional ownership appear to have a statistically larger effect from a change in dissemination than firms with a supermajority of institutional ownership. I have also used the median institutional ownership to separate the groups. I find similar results with the regulation measure, although the DEFA measure loses statistical significance in the test between the two groups. I cannot do a split of the data using the second research design because of power issues.

\subsection{Electronic Dissemination and Voting Results}

Next, I estimate how change in participation affects voting outcomes. Because uninstructed votes are treated differently, my predictions vary, depending on whether the vote is classified as routine or non-routine. Therefore, I have partitioned my sample based on the classification of the vote. Table 5 shows the results for routine votes. Because I want to partition my sample based on whether the vote is routine, and because Dodd-Frank has limited non-routine issues, I use the second empirical design, Design 2. The dependent variable for all columns 
is the percentage of the vote out of the total voting base that agrees with managements recommendation. Different meetings will have different voting bases, depending on the company charter. I use ISS data on both the voting base and management's recommendation. If management recommends voting against a shareholder proposal, and the charter specifies the voting base is votes for, against, or abstaining, the dependent variable is the number of votes against the proposal over the total number of votes for, against, and abstaining. The results are robust to using the outstanding votes as the base; however, the tabulated dependent variable closely captures the actual outcome of the vote and is the dependent variable management would care about. This leads to the following revised version of my Design 2 model:

$$
\text { ManagementFor }=\alpha+\beta_{1} \text { Regulation }+ \text { Controls }+ \text { Year }_{F E}+\text { Firm }_{F E}+\epsilon
$$

Table 5 Panel A reports results for whether adoption is associated with the percentage of the vote agreeing with managements recommendation. With both my measures of e-proxy adoption, I see a statistically significant increase in the percentage of votes in agreement with management. I include a falsification test in the third and fourth columns, where I look at non-routine rather than routine votes. For the non-routine votes, I do not find an increase in the percentage of the vote agreeing with managements recommendation. With non-routine votes, the vote is not given to the brokers. This result can be interpreted as the brokers being more likely than the retail investors to vote in agreement with management, but the retail investors not having statistically different voting patterns than institutional investors. 


\subsubsection{Director Elections}

Historically, there has been interest in the literature in director elections (Cai et al. 2009). Most director votes pass. However, low support, even if enough to elect the director, can lead to director turnover, as can be seen from the just say no campaigns of the 2000s. While there has been little study of the determinants of voter participation, there has been more study of the determinants of the voting outcomes for director elections. Focusing on this one area where there has been previous research allows me to better control for potential endogeneity. Examining a single type of vote makes interpretation of the economic significance easier. I will follow Cai et al. regarding the controls for my model. This leads to the following model, suppressing firm, year, and voting item subscripts:

$$
\begin{aligned}
\text { ManagementFor } & =\alpha+\beta_{1} D E F A+\beta_{2} \log (\text { assets })+\beta_{3} E B I T D A+\beta_{4} \text { entrenchment index } \\
& +\beta_{5} \text { abnormal CEO comp }+\beta_{6} \text { Board size }+\beta_{7} \text { Board holdings } \\
& +\beta_{8} \text { Percent outside director }+\beta_{9} \text { Majority voting } \\
& + \text { Year }_{F E}+\text { Industry } F E
\end{aligned}
$$

The dependent variable is the percentage of the vote in agreement with managements recommendation. The variable of interest is the DEFA measure of e-proxy treatment. Following Cai et al., I use the Gompers et al. (2003) governance index and the Bebchuk et al. (2005) entrenchment index. Cai et al. used industry level fixed effects. I exclude ISS recommendations because of data constraints. Cai et al. also included a litigation dummy, which I excluded because it was not significantly correlated with voting outcomes in their determinants test. I then compare the results with the estimated effect of e-proxy on voting outcomes using Design 2, which was originally created to estimate e-proxys effect on participation for non-routine votes.

The results are reported in Panel B of Table 5. Results using Design 2 pre-2010, when director elections would be classified as a routine issue, are reported in column 1 as a $1 \%$ 
coefficient, with marginal significance. Results using Design 2 post-2010, when director elections would be classified as a non-routine issue, are reported in column 3 as $.5 \%$, with marginal significance. When using the Cai et al. design, there is a statistically significant negative correlation driven by the post-2010 sample. In column 6, I estimate equation 5 with firm rather than industry fixed effects, and DEFA becomes insignificant.

\subsubsection{Canadian Notice and Access and Outcomes}

I then look at the relationship between notice and access and voting outcomes in Canada. One of the major advantages of the Canadian setting is the clean and detailed data on dissemination methods. For that reason, I use multiple measures to capture the slight variation in dissemination methods that were observable in Canada but were unobservable in the U.S.

Table 5 Panel $\mathrm{C}$ shows the relationship between the percent in agreement with management recommendation and notice and access use. In Panel $\mathrm{C}$, all regressions use a voting item description fixed effect and clustering. This design controls for the type of vote, such as whether it is a director election or a merger, but does not control for most of the variation between firms. From this, the results indicate that companies with higher voting in agreement with management recommendation are more likely to use notice and access. This correlation is driven by the firms decision to use notice and access for registered investors. This is consistent with a positive correlation driven by a selection effect where firms that are more (less) confident that they will obtain a desired voting outcome are more (less) likely to use notice and access, because firms have more information about registered investors and more options for how to reach out to them.

Table 5 Panel D also examines how notice and access relates to the percent in agreement with management recommendation, but this time with firm level fixed effects and clustering. Firm fixed effects better control for the variation in the firm investor base that might affect the underlying contentiousness of an election and the resulting selection effect that 
is highlighted in Panel C. When additional controls are added to the standard Design 2 controls to address voting item contentiousness and to try to mitigate selection effects, the sign of the relationship changes from positive to negative. Columns 1 and 2 show the significance of this effect with firm and meeting levels of clustering, respectively. Column 3 shows that the result is weaker without the additional controls for the positive signed endogeneity. Column 4 shows that, unlike the selection effects highlighted in Panel C, this effect is not being driven by registered investors; rather, the effect is seen most strongly using a measure of notice and access that captures the degree to which the investor base is subject to notice and access. This shows that while investor relations professionals are the most strategic about the way that information is disseminated to registered investors, because the investor relations professionals have the most information on those investors, the negative relationship between use of notice and access and the percent of the vote in agreement with managements recommendation is not being driven by registered investors exclusively. Also, whereas the relation is statistically significant, especially with meeting level clustering, the magnitude of the effect is less than one percent, meaning that it would only have an effect on the outcome for votes determined by very slim margins.

\subsection{Strategic Dissemination}

Lastly, I test for correlation between the decision to use the notice method and managements strategic reasons for wanting to increase participation. This test captures whether management appears to be investing more in dissemination during important or strategic elections. I restrict my sample to years after 2010, by which time all firms have had time to comply with e-proxy. It is important to also note that the post-2010 setting means that routine issues, where the previous test provided evidence that brokers vote are more in alignment with management than retail investors, are restricted to auditor ratification. Because there are two separate regimes, managements incentives found from this test might not be generalizable to pre-2010, when compensation and director votes were considered routine, 
or the current day, if Dodd-Frank were to be reversed. My strategic dissemination model, suppressing year, firm, and voting item subscripts, is as follows:

$$
\begin{aligned}
\text { PostalMail } & =\beta_{1} \text { proxy contest }+\beta_{2} \text { special }+\beta_{3} \text { vote fail } \\
& +\beta_{4} \text { Close Mangement votes }+ \text { Size }+ \text { Fixed effects }+\epsilon
\end{aligned}
$$

The dependent variable captures the voluntary use of postal mail to disseminate the proxy materials. The dependent variable is an indicator variable for whether the company filed its electronic notice as a DEFA14A on the SEC website, where a 1 represents that the company has not filed a notice. I have four measures of whether management sees the vote as important. The first is whether the vote is a proxy contest. The second is whether a special election has been called to vote on important issues that cannot wait until the next annual shareholder meeting. The third measure is whether the vote ex-post failed. The fourth measure is for close votes in which management is recommending investors vote in favor of the vote passing. I include year fixed effects to control for any time varying factors that might affect either method of dissemination or my ability to detect dissemination through EDGAR filings. Because dissemination methods tend to remain the same from year to year, I estimate this test with firm and then industry fixed effects. The firm fixed effects with a control for time-invariant firm variation includes much of the variation driven by management disclosure time and investor-base characteristics. The main nonstrategic benefits of electronic dissemination relate to economies of scale, so firms with larger investor bases and more costefficient investor relations departments are going to be more likely to adopt. Therefore, I include measures that reflect the size of the firm and the investor base.

In Table 6 , I find that there is a positive statistically significant correlation between postal dissemination and my measures of important votes. The first column shows the results with firm fixed effects. Three measures capturing important or strategic votes all have positive (negative) correlations with the measure of postal dissemination (electronic dissemination): proxy contest, special meeting, and close management votes. The second column also shows 
all four measures are at least weakly significant.

I estimate the same regression using the cleaner Canadian data. I have two specifications for the main treatment variable. In the first, the decision to use notice and access for any subsection of the investor base makes the variable equal to 1 to make the construct comparable to the U.S. setting. In the second, Notice and Access is on a scale from 0 to 2, where 0 represents no use of notice and access, 1 represents use only for a subgroup of the total investor base, and 2 represents all investors. Because it looks at use of notice and access, the sign of all coefficients should be the opposite of the coefficients in the other regressions. Because matching with COMPUSTAT greatly restricts the sample, I report results both with and without COMPUSTAT controls. Results are reported in columns 3-8. As with the U.S. sample, special elections have a positive correlation with use of physical dissemination. The choice of dissemination is also correlated with whether the vote failed.

Importantly, although this provides evidence that management is strategic with regard to dissemination, it does not imply anything about an agency conflict between investors and management. Particularly when considering the signaling theory of how electronic dissemination can affect participation, investors could be made better off if management disseminates using postal mail during only important elections.

\subsection{Descriptive Information about Dissemination Switches and Stratification}

To help interpret the results of Table 6, I document how many companies change dissemination methods. In Table 7, I show that within the U.S., dissemination methods change in about $4.4 \%$ of shareholder elections and that 166 companies switch methods within a single year. Most of the company switches within a single year are one-time switches to physical dissemination for a special meeting. This is consistent with my finding that only about $11 \%$ of special elections and proxy contests report using electronic dissemination, in comparison 
to $31 \%$ for the total population for the same time period.

Looking at the Canadian firms, I find a similar amount of switching. Of the 4026 firmmeeting observations I can successfully match with a previous firm-meeting observation, 200 observations have the company switching back to full access after having adopted notice and access. The use of notice and access seems similar across firms that I cannot match with a previous year, as 15.9\% (1457 observations) of the total sample uses e-proxy and 15.8\% (637 observations) of the matched sample. Of the 200 observations in which the firm switches dissemination, 135 have the company switch back for both registered and beneficial owners, 23 have the company switch registered investors back to full access, and 42 have the company switch only beneficial investors.

After implementation in the United States, there were reports from law firms of companies having different default forms of dissemination for different types of investors. NIRI surveyed investor relations departments in August of 2008 and reported that $42 \%$ took a stratified or hybrid approach. The stratification criteria were reported as being fairly evenly distributed across those who differentiated based on number of shares held, by beneficial versus registered holders, and other which included geographical delineations, 401K participants (who received full packages) and variants on the above (NIRI, 2008). There were even some reports of the default form of dissemination being tied to whether an investor had voted in the last election.

In the U.S. setting, I cannot observe when stratification is occurring, nor can I gauge the full extent of it. I assume any company disclosing that they used the notice method of dissemination used it for all investors who did not specifically call the company to request a physical copy. When the Canadians adopted their version of e-proxy in 2013, they required that companies disclose any stratification of the dissemination method. Although disclosure might moderate behavior, this can provide some estimate of how prevalent the practice might be in the United States. This is helpful because I could be considering firms treated that only are receiving a partial treatment.

Table 7, Panel B, shows the different criteria Canadian firms use to determine which 
of their investors receives which form of dissemination, given that the firm uses different dissemination methods for different investors. Only a small percentage of the Canadian sample uses stratification, and the majority that do use the beneficial versus registered investor distinction to determine method of dissemination. Because I rely strongly on the use of broker non-votes to identify retail investors, a registered/beneficial stratification is least likely to bias my results. These findings are different from NIRIs survey. This could imply that NIRIs survey data were not representative of the general population, or that disclosure of stratification moderates the behavior. For example, there were a small handful of Canadian companies that disclosed that their stratification criterion was to be determined or to follow and then filed an amended form right before the election disclosing actual dissemination. Because U.S. filers would not need to amend financial documents over last minute dissemination changes, they might be more likely to actually engage in last minute changes, although that behavior would need to be significantly more common than what I am observing in Canada to bias results.

Table 7, Panel $\mathrm{C}$ breaks down the percent of companies that use notice and access in the U.S. and Canada based on meeting type. The Canadian firms have lower adoption rates in part because the rule change happened more recently. For both countries, the rate of notice and access use for special meetings is much lower than the rate for annual meetings. The Canadians also have a lower rate for notice and access use for registered investors in proxy contests, but not beneficial investors, although there are only a handful of proxy contests in my sample. These basic statistics are in agreement with my interpretation of Table 6 .

\subsection{Robustness and Limitations}

A possible concern is that I might have over-controlled in an attempt to get rid of endogeneity, and have thus sacrificed informative variation. Table 8 addresses this concern by showing how the results change if I remove some of my controls and reduce the number of fixed effects. For all three columns, the effect of my treatment variable provides estimates that 
are similar to, or larger than, the estimates from my main research design (which had its results presented in Table 3).

One potential limitation to this study is that I may have misclassified some of the DEFA14A changes. Although a change in a companys disclosure policy is still a potential concern, I hand-checked the classification of over 400 elections in which only one DEFA14A was filed but multiple elections took place in that year to guarantee that I was reporting the correct dissemination method with the right election. The inclusion of the Canadian results discussed in previous sections helps to confirm that it is a dissemination change rather than a disclosure change driving the results.

Another potential limitation is related to outliers in the size of the firm or regarding election turnout. Reported regressions have truncated samples based on the size of the company, but all results are robust to removing that truncation. I have also removed elections with no reported participation, even if broker non-votes are reported; however, all results are robust to their inclusion.

I have performed several other untabulated robustness checks that I can provide upon request. Although I use the tightest fixed effects structure for my first empirical design, the results are robust to using firm*year fixed effects rather than meeting fixed effects and to the exclusion of the routine*year fixed effects in Table 3, Panel A. I also clean public float data from 2008 and control for the interaction between logged public float and non-routine votes with a 2006-2009 timeframe, and find similar results. 


\section{CHAPTER 6 CONCLUSION}

This paper shows that the means of information dissemination affects investor monitoring and corporate governance. It also provides evidence that management strategically invests more in dissemination for important votes, which shows that companies realize the role dissemination can play in corporate governance. My results confirm a decrease in participation occurred with the adoption of electronic dissemination in the United States and Canada. At the same time, the results may provide some reassurance to policymakers because of the selection. The firms that chose to use e-proxy were large with high total participation and with routine and non-controversial items on their ballots. In Canada, smaller firms instead chose to use notice and access; however, it was likewise most frequently used with noncontroversial items. Furthermore, if the signaling model explains this result, retail investors are being made better off.

These findings are of interest to policymakers. American policymakers have frequently stated interest in research related to this topic specifically and generally around shareholder participation. This study also pertains to more than American policy; very public SEC debates such as this one affect policy positions of other countries too. E-proxy has made it easier to adopt the notice and access method than is true in many international systems. Member states of the European Union could use electronic dissemination, but companies were re-

quired to obtain written consent before sending information electronically (Zetzsche, 2007) ${ }^{1}$. Surveys of Japanese companies found the burdensome consent requirements explained why less than 3\% of companies had adopted the Japanese version of e-proxy (Tanaka, 2015). Although making the system more permissive could lead to clear efficiency gains, the negative reaction from firms in the United States in the early years of adoption raised concern. Nowhere was that concern clearer than with the Canadian Securities Administration.

1. Article 17 (3) of the Transparency Directive 
Part of what makes my paper useful to regulators is the lack of research on retail investor participation. Corporate finance has a large literature on the effects of proxy voting and how it shifts the balance of power in agency conflicts with asymmetric information. Theories on the effects of corporate proposals on the value of the firm implicitly make assumptions regarding whether uninformed control creates or destroys value. Recent papers show proxy voting can lead to positive monitoring effects. Ertimur et al. (2010) find poorly performing managers were more likely to have their compensation package rejected in say on pay votes. Bach and Metzger (2014) similarly show that managers who do not implement approved corporate governance proposals are dismissed. Cuñat, Gine, and Guadualupe (2012, 2013) find positive valuation effects from approved shareholder proposals. While there is a large literature on voting outcomes, the literature has rarely mentioned participation.

Over time, ownership has become more concentrated, with many retail investors investing through institutional investors. Papers have examined the role of institutional investors in corporate governance and shareholder outcomes. Appel et al. (2016) find an increase in passive shareholders due to classification in the Russell 2000 leads to more involvement by activist investors. The natural assumption is that retail investors are the default, and that an increase in institutional investors is the same as a decrease in retail investors. However, these papers do not look directly at retail investor participation in shareholder meetings. Thus, they cannot determine if institutional ownership increases corporate governance because institutions are frequently required to monitor or because they are more sophisticated voters. My findings suggest that in studies using voting data before 2010, low retail investor participation was causing discretion to fall toward brokerages, who vote differently than retail investors themselves. 


\section{REFERENCES}

[1] Hearings on h.r. 1493, h.r. 1821, and h.r. 2019 before the house committee on interstate and foreign comerce, 78th cong., 1st sess. 172, 1943. Testimony of Ganson Purcell.

[2] Andrew Ackerman and Patrick O'Connor. Print Is Dead? Not in Mutual-Fund Reports - WSJ, 2006.

[3] L. Aguilar. Ensuring the proxy process works for shareholders. Speech presented at Roundtable on Proxy Voting, Washington, D.C., February 2015.

[4] Ali C. Akyol, Konrad Raff, and Patrick Verwijmeren. The elimination of broker voting in director elections. Finance Research Letters, 21:3439, 2017.

[5] Ian Appel, Todd Gormley, and Donald Keim. Standing on the shoulders of giants: The effect of passive investors on activism. SSRN, 2016.

[6] Paul Atkins. Shareholder rights, the 2008 proxy season, and the impact of shareholder activism. Speech before U.S. Chamber of Commerce, Washinngton, D.C., July 2008.

[7] Lucian Bebchuk, Alma Cohen, and Allen Ferrell. What matters in corporate governance? The Review of Financial Studies, 22(2):783-827, 2009.

[8] Bo Becker, Daniel Bergstresser, and Guhan Subramanian. Does shareholder proxy access improve firm value? evidence from the business roundtable challenge. The Journal of Law and Economics, 56:127160, 2013.

[9] Elizabeth Blankespoor, Gregory S. Miller, and Hal D. White. The Role of Dissemination in Market Liquidity: Evidence from Firms' Use of Twitter. The Accounting Review, 89(1):79-112, jan 2014.

[10] Traci L. Mach Brian K. Bucks, Arthur B. Kennickell and Kevin B. Moore. Changes in u.s. family finances from 2004 to 2007: Evidence from the survey of consumer finances. Technical report, Federal Reserve, https://www.federalreserve.gov/econres/files/2007_scf09.pdf, 2009.

[11] James A. Brickley, Ronald C. Lease, and Clifford W. Smith. Ownership structure and voting on antitakeover amendments. Journal of Financial Economics, 20:267291, 1988.

[12] Broadridge. Distribution and voting trends in 2015. http://media.broadridge.com/documents/Broadridge-Distribution-and-Voting-Trends2015.pdf, 2015.

[13] Broadridge. Analysis of distribution and voting trends fiscal year ending june 30, 2016. Technical report, Broadridge, https://www.broadridge.com/_assets/pdf/broadridgeanalysis-of-traditional-and-notice-access-issuers-na-adoption-distribution-andvoting.pdf, 2016. 
[14] Brian J. Bushee, John E. Core, Wayne Guay, and Sophia J.W. Hamm. The Role of the Business Press as an Information Intermediary. Journal of Accounting Research, 48(1):1-19, mar 2010.

[15] Robert M. Bushman and Abbie J. Smith. Financial accounting information and corporate governance. Journal of Accounting and Economics, 32(1):237 - 333, 2001.

[16] Jie Cai, Jacqueline L. Garner, and Ralph A. Walkling. Electing Directors. Journal of Finance, 64(5):2389-2421, 2009.

[17] Hans B. Christensen, Eric Floyd, Lisa Yao Liu, and Mark Maffett. The real effects of mandated information on social responsibility in financial reports: Evidence from mine-safety records. Journal of Accounting and Economics, 64(2-3):284304, 2017.

[18] Jay Clayton. Governance and transparency at the commission and in our markets. Speech, November 2017. https://www.sec.gov/news/speech/speech-clayton-2017-1108\#_ftn20.

[19] Vicente Cuñat, Mireia Gine, and Maria Guadalupe. The vote is cast: The effect of corporate governance on shareholder value. The Journal of Finance, 67(5):19431977, 2012.

[20] Vicente Cuñat, Mireia Gine, and Maria Guadalupe. Corporate governance and value: Evidence from close calls on shareholder governance proposals. Journal of Applied Corporate Finance, 25(1):44-54, 2013.

[21] Kim E.H. Davis G.F. Business ties and proxy voting by mutual funds. Journal of Financial Economics, 85(2):552-570, 2007.

[22] Eugene F. Fama and Kenneth R. French. Disagreement, Tastes, and Asset Prices. SSRN Electronic Journal, nov 2005.

[23] Vyacheslav Fos and Wei Jiang. Out-of-the-money ceos: Private control premium and option exercises. The Review of Financial Studies, 29(6):1549-1585, 2016.

[24] Paul Gompers, Joy Ishii, and Andrew Metrick. Corporate governance and equity prices*. The Quarterly Journal of Economics, 118(1):107-156, 2003.

[25] Jeffrey N Gordon. Proxy Contests in an Era of Increasing Shareholder Power: Forget Issuer Proxy Access and Focus on E-Proxy. Vanderbilt Law Review, 61(2):475-496, 2008.

[26] Oliver Hart and Luigi Zingales. Companies Should Maximize Shareholder Welfare Not Market Value. SSRN Electronic Journal, aug 2017.

[27] National Investor Relations Institute. Notice and access and nyse rule 452- one step forward and two steps back? Technical report, https://www.sec.gov/comments/s7-2209/s72209-5.pdf, 2009. 
[28] Dominic Jones. Firms blame broadride, sec for e-proxy snafus. IR Web Report, 2008.

[29] Marcel Kahan and Edward Rock. The Hanging Chads of Corporate Voting. SSRN, 2008.

[30] Stuart Kaiser, Ben Snider, and Peter Lewis. An equity investor' s guide to the Flow of Funds Accounts. Technical report, Goldman Sachs, 2013.

[31] Jonathan M. Karpoff, Allison Koester, D. Scott Lee, and Gerald S. Martin. Proxies and databases in financial misconduct research. The Accounting Review, forthcoming, 2017.

[32] Elisabeth Kempf, Alberto Manconi, and Oliver Spalt. Distracted shareholders and corporate actions. The Review of Financial Studies, 30(5):1660-1695, 2017.

[33] April Klein Kose John. Shareholder proposals and corporate governance. NYU Working Paper, 1995.

[34] Christian Leuz, Peter Wysocki, and Comments Welcomed. Economic Consequences of Financial Reporting and Disclosure Regulation: A Review and Suggestions for Future Research *. SSRN, 2008.

[35] Martin Lipton and Steven Rosenblum. The University of Chicago law review., volume 58. The University of Chicago Law Review, jan 1991.

[36] Davide Lombardo and Marco Pagano. Law and Equity Markets: A Simple Model. SSRN Electronic Journal, oct 2000.

[37] Anne Mangen, Bente R. Walgermo, and Kolbjrn Brnnick. Reading linear texts on paper versus computer screen: Effects on reading comprehension. International Journal of Educational Research, 58:61 - 68, 2013.

[38] Paul Muter, Susane A. Latrmouille, William C. Treurniet, and Paul Beam. Extended reading of continuous text on television screens. Human Factors, 24(5):501-508, 1982.

[39] David J. Oborne and Doreen Holton. Reading from screen versus paper: there is no difference. International Journal of Man-Machine Studies, 28(1):1 - 9, 1988.

[40] Code of Federal Regulation. 240.14a-16(h)(2)(i).

[41] Michael Piwowar. Proxy voting roundtable. Speech presented at SEC Roundtable, Washington, DC, 2015.

[42] Robert Pozen. Institutional investors: The reluctant activists. Harvard Business Review, pages 140-149, 1994.

[43] William H. Riker and Peter C. Ordeshook. A Theory of the Calculus of Voting. American Political Science Review, 62(01):25-42, mar 1968.

[44] Patrick J. Ryan. Rule 14a-8, institutional shareholder proposals, and corporate democracy. Georgia Law Review, 23:97, 1988-1989. 
[45] P. Lewis S. Kaiser, B. Snider. An equity investor's guide to the flow of funds accounts. Technical report, Federal Reserve Board, Lionshares and Goldman Sachs Global ECS Research, 2013.

[46] Mary Shapiro. Speech by sec chairman: Address to the practising law institute's 41st annual institute on securities regulation, Nov 2009.

[47] Dov Solomon. The Voice: The Minority Shareholder's Perspective. Nevada Law Journal, 17:739-772, 2017.

[48] Michael Spence. Job market signaling. The Quarterly Journal of Economics, 87(3):355$374,1973$.

[49] Debra M. Switchenko. Reading from crt versus paper: The crt-disadvantage hypothesis re-examined. Proceedings of the Human Factors Society Annual Meeting, 28(5):429-430, 1984.

[50] Wataru Tanaka. Shareholder Meetings and Corporate Governance: With a Focus on Electronic Provision of Reference Materials for Shareholder Meetings. Public Policy Review, 11(3):451-474, July 2015.

[51] Christoph Van der Elst. Revisiting Shareholder Activism at AGMs: Voting Determinants of Large and Small Shareholders. SSRN Electronic Journal, jul 2011.

[52] Wohlstetter. Pension fund socialism: Can bureaucrats run the blue chips? Harvard Business Review, 71:78, 1993. 
APPENDIX A

APPENDIX A: FIGURES 
Figure 1: E-proxy Before and After

Companies had to choose between two new dissemination methods: full access and notice. Large accelerated filers were required to make the switch on January 1, 2008, and all public companies were required to adopt by January 1, 2009. Companies could freely switch back and forth between full access and notice.

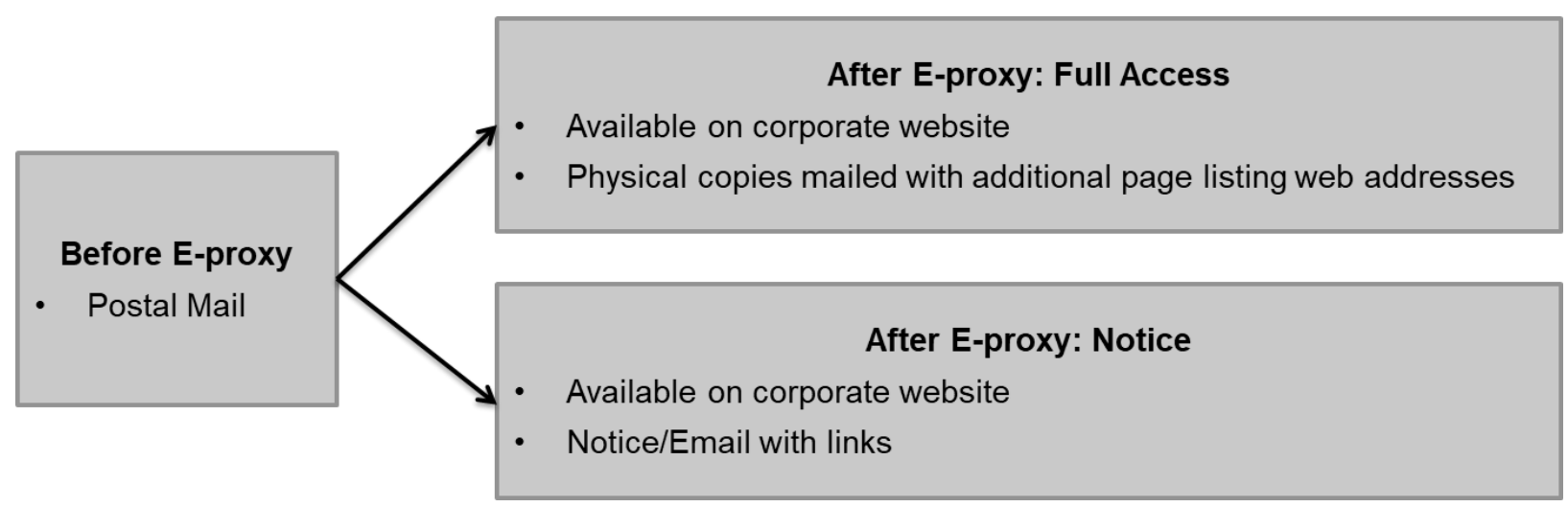


Figure 2: Notice

Below is an example of a notice and access form from Computershare. Alcoa filed this notice as a DEFA14A on March 17, 2017. Two major companies are in charge of proxy dissemination:

Computershare and Broadridge.

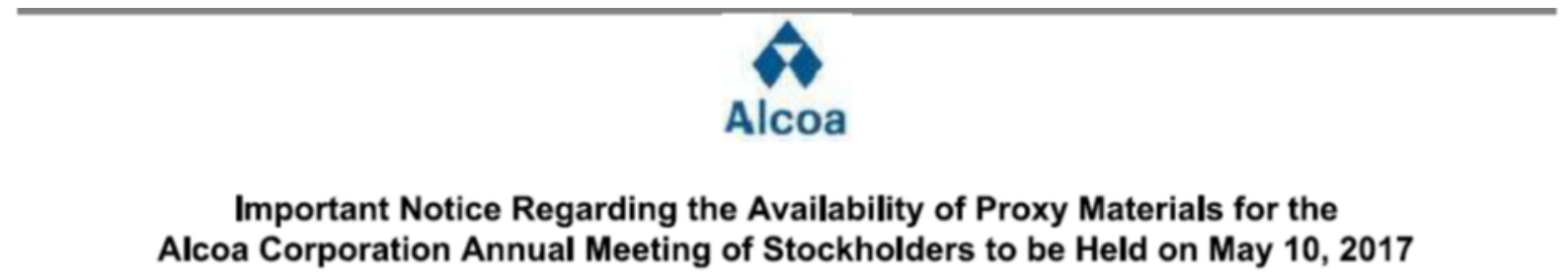

You are receiving this notice that the proxy materials for the Alcoa Corporation 2017 Annual Meeting of Stockholders are available on the Internet. Follow the instructions below to view the materials and vote online or request a paper or email copy. Information about the items to be voted on and the location of the annual meeting are provided on the reverse side of this notice.

This communication presents only an overview of the more complete proxy materials that are available to you on the Internet or by mail. We encourage you to access and review all of the important information contained in the proxy materials before voting.

The 2017 Proxy Statement and 2016 Annual Report (including Form 10-K) are available at:

\section{www.ViewMaterial.com/AA}

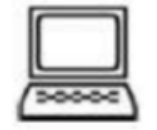

Easy Online Access - A Convenient Way to View Proxy Materials and Vote

When you go online to view materials, you can also vote your shares.

Step 1: Go to www. ViewMaterial.com/AA and view the proxy materials.

Step 2: Click the icon to vote your shares.

Step 3: Enter the 11 digit control number (located by the arrow in the box below).

Step 4: Follow the simple instructions to record your vote.

You are able to vote online until 6:00 a.m. (EDT) on May 10, 2017.

When you go online, you can also help the environment by consenting to receive electronic delivery of future materials.

Obtaining a Copy of the Proxy Materials - If you want to receive a paper or email copy of the proxy materials, you must request one. There is no charge to you for requesting a copy. Please make your request for a copy as instructed on the reverse side on or before April 26, 2017 to facilitate timely delivery. 


\section{Figure 3: Ownership Structure}

This figure shows how proxy information flows through the ownership structure. Information flows from the firm through any relevant intermediaries to the investors. The boxes with the blue border (gray if printed black and white) show the groups that will attend the shareholder meetings. This information matters because the broker has the right to make discretionary votes for beneficially owned shares for routine issues when voting instructions have not been received after legal dissemination of proxy materials. I use the difference between participation in votes in which brokers have discretionary voting rights and those in which they do not to estimate the level of retail investor nonparticipation.

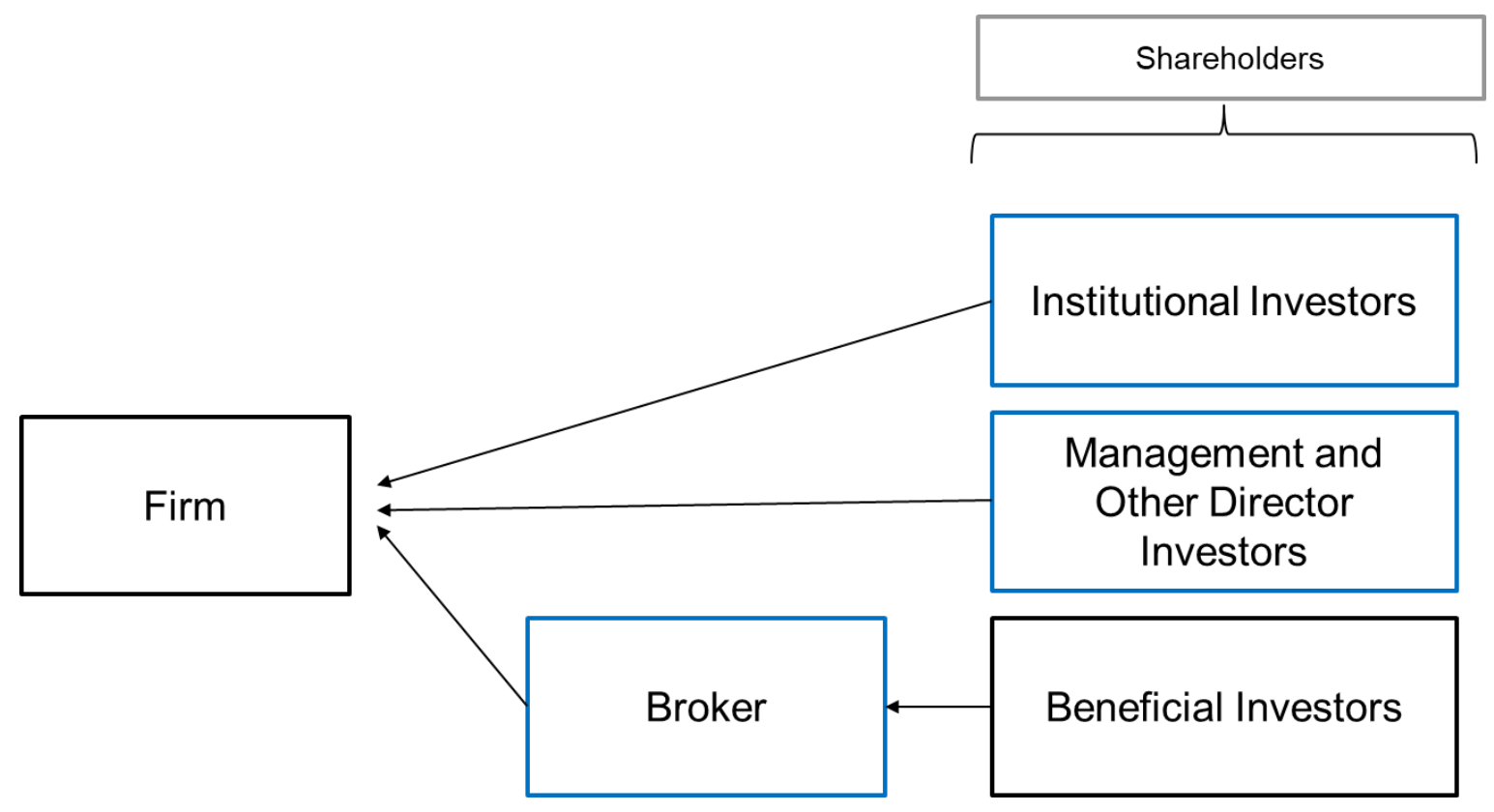




\section{Figure 4: Routine versus Non-routine}

Participation can only be accurately measured on non-routine proposals. For routine proposals, brokers can make discretionary votes on shares that are uninstructed ten days before the shareholder meeting. Thus, the changing definition of non-routine proposals throughout the sample explains the composition of votes in my sample. Changes in the definition are caused by implementation of Dodd-Frank.

\begin{tabular}{|c|c|c|}
\hline Time Period & Routine Proposals & Non-routine Proposals \\
\hline $\begin{array}{l}\text { Pre-Jan 1, } \\
2010\end{array}$ & $\begin{array}{l}\text { - } \text { Auditor ratification } \\
\text { - } \text { Non-contested election of } \\
\text { directors } \\
\text { - } \text { Matters relating to executive } \\
\text { - De-staggen the board of } \\
\text { directors } \\
\text { - Implement majority voting in } \\
\text { - } \text { director elections } \\
\text { - } \quad \text { Provermajority requirements } \\
\text { - } \quad \text { Pronsent } \\
\text { - } \text { meeting use of written } \\
\text { Opt out of certain types of } \\
\text { takeover provisions }\end{array}$ & $\begin{array}{l}\text { - Is not submitted to shareholders } \\
\text { by means of a proxy statement } \\
\text { comparable to that specified in } \\
\text { Schedule 14-A of the SEC } \\
\text { - } \quad \text { Proxy contests } \\
\text { - } \text { Mergers and consolidations } \\
\text { - } \text { Ahareholder appraisal rights } \\
\text { mortgages } \\
\text { - Authorizations or increased } \\
\text { authorizations of company } \\
\text { indebtedness } \\
\text { Authorizations or increased } \\
\text { authorizations of classes of } \\
\text { preferred stock } \\
\text { Alterations of the terms or } \\
\text { conditions of existing stock or } \\
\text { indebtedness } \\
\text { Modifications of preemptive } \\
\text { rights } \\
\text { Changes to stockholder meeting } \\
\text { quorum requirements } \\
\text { Alterations of voting provisions } \\
\text { of stock } \\
\text { Authorizations or issuances of } \\
\text { stock or stock options to } \\
\text { directors, officers, or employees } \\
\text { in amounts that exceed } 5 \% \text { of } \\
\text { outstanding common shares } \\
\text { Authorizations or increased } \\
\text { authorizations of profit sharing } \\
\text { or special remuneration plans } \\
\text { that exceed } 10 \% \text { of average } \\
\text { mannual income before taxes } \\
\text { firm's malue exceeds } 20 \% \text { of the } \\
\text { lines of businesses } \\
\text { - }\end{array}$ \\
\hline
\end{tabular}


Figure 4, Continued

\begin{tabular}{|c|c|c|}
\hline & & $\begin{array}{l}\text { - Sales of property or earning } \\
\text { power approximating } 20 \% \text { or } \\
\text { more of those existing before the } \\
\text { transaction } \\
\text { - Authorizations of transactions } \\
\text { not in the ordinary course of } \\
\text { business in which officers, } \\
\text { directors, or substantial security } \\
\text { holders have a direct or indirect } \\
\text { interest } \\
\text { Reductions in earned surpluses of } \\
51 \% \text { or more, or red }\end{array}$ \\
\hline $\begin{array}{l}\text { Jan } 1,2010- \\
\text { July } 21,2010\end{array}$ & $\begin{array}{l}\text { - } \\
\text { - } \text { Matiters relating to executive } \\
\text { - } \quad \text { De-staggen the board of } \\
\text { directors } \\
\text { - } \text { Implement majority voting in } \\
\text { director elections } \\
\text { - } \quad \text { Supermajority requirements } \\
\text { - } \text { Provide for the use of written } \\
\text { consent } \\
\text { - } \text { Provide rights to call a special } \\
\text { meeting } \\
\text { Opt out of certain types of } \\
\text { takeover provisions }\end{array}$ & $\begin{array}{ll} & \text { All Elections of directors } \\
\text { - } & \text { See above }\end{array}$ \\
\hline $\begin{array}{l}\text { July } 21,2010- \\
\text { Jan } 2012\end{array}$ & $\begin{array}{l}\text { - } \\
\text { - } \quad \text { Duditor ratification } \\
\text { directors } \\
\text { - } \quad \text { Implement majority voting in } \\
\text { director elections } \\
\text { - } \quad \text { Supermajority requirements } \\
\text { - } \text { Provide for the use of written } \\
\text { consent } \\
\text { - } \quad \text { Provide rights to call a special } \\
\text { meeting } \\
\text { - } \text { Opt out of certain types of } \\
\text { takeover provisions }\end{array}$ & $\begin{array}{l}\text { - } \text { Election of directors } \\
\text { - } \text { Matters relating to executive } \\
\text { - } \text { compensation } \\
\text { - See above }\end{array}$ \\
\hline $\begin{array}{l}\text { Jan 2012- } \\
\text { Present }\end{array}$ & - $\quad$ Auditor ratification & $\begin{array}{ll}\text { - } & \text { Election of directors } \\
\text { - } & \text { Matters relating to executive } \\
\text { - } & \text { Dempensation } \\
\text { - } & \text { Implement majority voting in } \\
& \text { director elections }\end{array}$ \\
\hline
\end{tabular}


Figure 4, Continued

\begin{tabular}{|l|l|l|}
\hline & $\begin{array}{l}\text { Eliminate supermajority } \\
\text { requirements }\end{array}$ \\
$\bullet$ & Provide for the use of written \\
& consent \\
$\bullet$ & Provide rights to call a special \\
& meeting \\
$\bullet$ & Opt out of certain types of \\
& takeover provisions \\
& $\bullet$ & See above \\
\hline
\end{tabular}




\section{Figure 5: Broadridge}

This table shows Broadridge's disclosures to the SEC regarding investor participation. They appear to show investor participation decreases, particularly for smaller investors. Outside of my paper, this table is the only other empirical look at the effect of this regulation, and it reports only total numbers, without any empirical design or controls for other factors.

\section{But the Savings Have Come at the Expense of "Main Street" Participation}

\section{"Matched" Account Participation: Before and After Notice \& Access}

Participation has decreased among the same account holders, especially among smaller investors.

\begin{tabular}{|l|r|r|r|r|}
\hline $\begin{array}{l}\text { Size of } \\
\text { Account } \\
\text { (share range) }\end{array}$ & $\begin{array}{c}\text { Number of } \\
\text { Accounts in Range }\end{array}$ & $\begin{array}{l}\text { \# that Voted } \\
\text { Before N\&A }\end{array}$ & $\begin{array}{l}\text { \# that Voted } \\
\text { After N\&A }\end{array}$ & Percent Change +/(-) \\
\hline$<1000$ & $5,982,606$ & 868,027 & 343,941 & \multicolumn{1}{|c|}{$(61)^{*}$} \\
\hline $1,000-4,999$ & 648,656 & 143,527 & 55,402 & $(61)$ \\
\hline $5,000-9,999$ & 61,266 & 14,685 & 7,244 & $(51)$ \\
\hline $10,000-49,999$ & 40,862 & 10,301 & 5,605 & $(46)$ \\
\hline$>50,000$ & 7,657 & 2,324 & 1,626 & $(30)$ \\
\hline Total & $6,741,047$ & $1,038,864$ & 413,818 & $(60)$ \\
\hline
\end{tabular}

"Matched" accounts denotes the same account. Comparison of voting at the same companies -- with N\&A (current meeting) to without N\&A (prior meeting, pre-N\&A rules). Based on all 164 corporate shareholder meetings from July 1, 2007 - April 30, 2008.

* Includes mailings of a $2^{\text {nd }}$ Notice (with a ballot) and full packages as a result of 'consents' and issuer stratification.

\begin{tabular}{|c|c|c|c|c|}
\hline $\begin{array}{c}\text { Number of } \\
\text { Notice } \\
\text { Recipients }\end{array}$ & $\begin{array}{c}\text { Number of Notice } \\
\text { Recipients that Visited the } \\
\text { Specified URL and } \\
\text { Selected "Read Materials" }\end{array}$ & $\%$ & $\begin{array}{c}\text { Number of Notice } \\
\text { Recipients that Visited the } \\
\text { Specified URL and } \\
\text { Selected "Vote" }\end{array}$ & $\%$ \\
\hline 812,772 & 2,593 & 0.47 & 21,115 & 3.25 \\
\hline
\end{tabular}

Notes

- Includes all 40 registrants that used Notice \& Access (meetings from 6/1/08 to 9/26/08).

- A total of 812,772 account holders received a Notice by mail.

- Going to the URL and clicking on the "Vote" option opens a voting ballot and provides a link to view detailed information.

- The "Read Materials" option presents the materials and includes the option to vote. 
Figure 5, Continued

Investors who receive proxy information (mail or email) are more likely to use the Internet to vote than are investors who receive a Notice only.

\begin{tabular}{|c|c|c|c|c|c|}
\hline Receipt of Info & $\begin{array}{l}\text { Total Items } \\
\text { Sent } \\
\text { (\#) }\end{array}$ & $\begin{array}{l}\text { Voting by } \\
\text { Paper Ballot } \\
\text { (\#) }\end{array}$ & $\begin{array}{c}\text { Voting by } \\
\text { Paper Ballot } \\
\text { (\%) }\end{array}$ & $\begin{array}{l}\text { Voting by } \\
\text { Internet Ballot } \\
\text { (\#) }\end{array}$ & $\begin{array}{c}\text { Voting by } \\
\text { Internet Ballot } \\
(\%)\end{array}$ \\
\hline Full Set Sent by Mail & 110,118 & 34,787 & 31.8 & 26,626 & 23.0 \\
\hline Notice Sent by Mail & 812,772 & 1,677 & 0.4 & 21,115 & 3.3 \\
\hline Email Including Links & 328,651 & 65 & 0.1 & 37,351 & 12.5 \\
\hline
\end{tabular}

Notes

- All 40 Notice \& Access corporate issuers with meetings 6/1/08 to 9/26/08

- Distributions ranged from 1,226 to 966,578 accounts/issuer.

- Total of 1,875,021 account holders. ProxyEdge (624,080 accounts) is a proprietary platform for institutional investors and financial advisors, and it is excluded.

- Response rates represent an average of averages, i.e., on average for a given issuer. Differences due to rounding.

- "Full Set by Mail" includes prior consents and issuer stratification of mailings.

- "Email" delivery provides essentially the same experience for an account holder, with or without Notice \&

Access, and is based on prior consent.

- Prior "Consents" on file for 2.5 million account holders. Processing of prior consents and issuer stratification (e.g., full package to larger accounts) resulted in $11 \%$ of items mailed by full package $(7 / 1 / 07$ to $6 / 30 / 08)$. 
Figure 6: Standard Canadian Disclosure in Proxy Information Circular

This shows a standard disclosure in a proxy information circular, the Canadian equivalent of the DEF14A proxy document, explaining notice and access.

\section{NOTICE AND ACCESS}

In accordance with the notice-and-access rules adopted by the Ontario Securities Commission under NI 54-101, the Company has sent its proxy-related materials directly to registered holders and non-objecting beneficial owners using notice-and-access. Therefore, although shareholders still receive a proxy or Voting Instruction Form (as applicable) in paper copy, this Information Circular, annual consolidated financial statements and related MD\&A are not physically delivered. Instead, shareholders may access these materials on the Company's website at http:// 2 or under the Company's profile page on SEDAR at www.sedar.com

Registered holders or beneficial owners may request paper copies of the Meeting materials be sent to them by postal delivery at no cost to them. Requests may be made up to one year from the date the Meeting materials are posted on the Company's website. In order to receive a paper copy of the Meeting materials or if you have questions concerning Notice-and-Access, please call toll free at Requests for paper materials should be received by Monday, April 2018 in order to receive the Meeting materials in advance of the Meeting. 
APPENDIX B

APPENDIX B: TABLES 
B1. Variable Definitions

\begin{tabular}{|c|c|}
\hline Variable & Definition \\
\hline Participation & $\begin{array}{l}\text { The percentage of votes (for, against, abstaining, and } \\
\text { withholding) out of outstanding shares }\end{array}$ \\
\hline Management For & $\begin{array}{l}\text { The percent of the vote in agreement with management } \\
\text { recommendations out of voting base as reported in ISS }\end{array}$ \\
\hline Non-routine & $\begin{array}{l}\text { Votes where there were non-votes because brokers do not } \\
\text { have discretionary voting rights when beneficial shareholders } \\
\text { do not participate }\end{array}$ \\
\hline DEFA & $\begin{array}{l}\text { Indicator variable equal to } 1 \text { if I observe a DEFA14A notice, } \\
\text { which means the firm is using the notice and access method of } \\
\text { dissemination }\end{array}$ \\
\hline Postal Mail & $\begin{array}{l}\text { Indicator variable equal to } 1 \text { for U.S. observations if I do not } \\
\text { observe a DEFA14A notice, which means the firm is using the } \\
\text { full access method of dissemination, and equal to } 1 \text { for } \\
\text { Canadian observations if firm reports to use postal } \\
\text { dissemination/full access for all investors }\end{array}$ \\
\hline DEFA*non-routine & The interaction between DEFA and non-routine \\
\hline Regulation & $\begin{array}{l}\text { Large accelerated filers interacted with } 2008 \text { and all firms } \\
\text { starting with } 2009\end{array}$ \\
\hline $\begin{array}{l}\text { Regulation*non- } \\
\text { routine }\end{array}$ & The interaction between regulation and non-routine \\
\hline Notice and Access & $\begin{array}{l}\text { Variable equal to } 2 \text { if the firm disclosed that they were using } \\
\text { Notice and Access, the Canadian version of e-proxy, for all } \\
\text { investors, to } 1 \text { for some subset of investors, and to } 0 \text { if they } \\
\text { used full access. }\end{array}$ \\
\hline $\begin{array}{l}\text { Beneficial Investor } \\
\text { Notice and Access }\end{array}$ & $\begin{array}{l}\text { Indicator variable equal to } 1 \text { if firm disclosed that notice and } \\
\text { access would be used for beneficial investors }\end{array}$ \\
\hline $\begin{array}{l}\text { Registered Investor } \\
\text { Notice and Access }\end{array}$ & $\begin{array}{l}\text { Indicator variable equal to } 1 \text { if firm disclosed that notice and } \\
\text { access would be used for registered investors }\end{array}$ \\
\hline $\begin{array}{l}\text { Only Notice and } \\
\text { Access }\end{array}$ & $\begin{array}{l}\text { Indicator variable equal to } 1 \text { if firm disclosed that notice and } \\
\text { access would be used for either beneficial or registered } \\
\text { investors }\end{array}$ \\
\hline $\begin{array}{l}\text { Supermajority } \\
\text { Institutional } \\
\text { Ownership }\end{array}$ & $\begin{array}{l}\text { Firms with more than } 66 \% \text { ownership by institutional owners } \\
\text { as defined by Thompson Reuters's } 13 \mathrm{~F} \text { Institutional } \\
\text { Ownership data }\end{array}$ \\
\hline
\end{tabular}




\section{B.1, Continued}

\begin{tabular}{|c|c|}
\hline $\begin{array}{l}\text { Lower Institutional } \\
\text { Ownership }\end{array}$ & $\begin{array}{l}\text { Firms with less than } 66 \% \text { ownership by institutional owners } \\
\text { as defined by Thompson Reuters's } 13 \text { F Institutional } \\
\text { Ownership data }\end{array}$ \\
\hline Ln(Total assets) & Natural logarithm of total assets from COMPUSTAT \\
\hline $\operatorname{Ln}($ Acquisition $)$ & Natural logarithm of acquisition data from COMPUSTAT \\
\hline Ln(Outstanding) & Natural logarithm of outstanding shares from ISS \\
\hline Delta EPS & $\begin{array}{l}\text { The change in dilutive earnings per share scaled by total } \\
\text { assets between time t and } \mathrm{t}-1 \text {, winsorized at the } 1 \% \text { and } 99 \% \\
\text { levels }\end{array}$ \\
\hline Ln(Market value) & $\begin{array}{l}\text { Natural logarithm of the market value at fiscal year-end as } \\
\text { reported in COMPUSTAT }\end{array}$ \\
\hline Annual meeting & $\begin{array}{l}\text { Indicator variable equal to } 1 \text { if the vote was part of an annual } \\
\text { meeting, and } 0 \text { otherwise }\end{array}$ \\
\hline Special meeting & $\begin{array}{l}\text { Indicator variable equal to } 1 \text { if the vote was part of a special } \\
\text { meeting, and } 0 \text { otherwise }\end{array}$ \\
\hline Proxy contest & $\begin{array}{l}\text { Indicator variable equal to } 1 \text { if the vote was part of a proxy } \\
\text { contest, and } 0 \text { otherwise }\end{array}$ \\
\hline Director Election & $\begin{array}{l}\text { Indicator variable equal to } 1 \text { if the vote was for the election of } \\
\text { a director, and } 0 \text { otherwise }\end{array}$ \\
\hline Auditor Ratification & $\begin{array}{l}\text { Indicator variable equal to } 1 \text { if the vote was for the } \\
\text { ratification of the external auditor, and } 0 \text { otherwise }\end{array}$ \\
\hline $\begin{array}{l}\text { Elect Director after } \\
2010\end{array}$ & $\begin{array}{l}\text { Indicator variable for if the vote for the election of a director } \\
\text { after } 2010 \text {, and } 0 \text { otherwise }\end{array}$ \\
\hline Amend compensation & $\begin{array}{l}\text { Indicator variable equal to } 1 \text { if the vote was to amend an } \\
\text { omnibus stock or option plan, and } 0 \text { otherwise }\end{array}$ \\
\hline $\begin{array}{l}\text { Approve } \\
\text { compensation }\end{array}$ & $\begin{array}{l}\text { Indicator variable for if the vote was to approve compensation } \\
\text { plan otherwise equal to } 0\end{array}$ \\
\hline $\begin{array}{l}\text { Close management } \\
\text { vote }\end{array}$ & $\begin{array}{l}\text { Indicator variable for if the vote has less than } 70 \% \text { support } \\
\text { and management recommended support }\end{array}$ \\
\hline $\begin{array}{l}\text { Ln(Total } \\
\text { Assets })^{*} \text { non-routine }\end{array}$ & Ln(Total Assets) interacted with non-routine \\
\hline $\begin{array}{l}\text { Ln(Market } \\
\text { value)*non-routine }\end{array}$ & Ln(Market value) interacted with non-routine \\
\hline $\begin{array}{l}\text { Delta EPS*non- } \\
\text { routine }\end{array}$ & Delta EPS interacted with non-routine \\
\hline Annual*non-routine & Annual interacted with non-routine \\
\hline Merger & $\begin{array}{l}\text { Indicator variable equal to } 1 \text { if the vote was related to a } \\
\text { merger or acquisition }\end{array}$ \\
\hline
\end{tabular}




\section{B.1, Continued}

\begin{tabular}{|l|l|} 
Vote Fail & $\begin{array}{l}\text { Indicator variable equal to } 1 \text { if the vote failed to pass, and 0 } \\
\text { otherwise }\end{array}$ \\
\hline Sponsor & $\begin{array}{l}\text { Indicator variable equal to } 1 \text { if management sponsored the } \\
\text { vote }\end{array}$ \\
\hline EBITDA & From COMPUSTAT winsorized at the 1\% and 99\% levels \\
\hline Entrenchment Index & $\begin{array}{l}\text { As defined in Bebchuk et al. (2005) data either from } \\
\text { Bebchuk's website or ISS Governance data }\end{array}$ \\
\hline $\begin{array}{l}\text { Abnormal CEO } \\
\text { Compensation }\end{array}$ & $\begin{array}{l}\text { The residual from a simple compensation regression of all } \\
\text { Execucomp firms during my sample period }\end{array}$ \\
\hline Board size & $\begin{array}{l}\text { The number of directors ISS Director data has listed in a firm } \\
\text { year }\end{array}$ \\
\hline Board Holdings & $\begin{array}{l}\text { The cumulative percent control of voting power held by the } \\
\text { board in a year from ISS Director Data }\end{array}$ \\
\hline Percent Independent & $\begin{array}{l}\text { The fraction of directors in a firm year listed in ISS Director } \\
\text { data as independent }\end{array}$ \\
\hline Majority voting & $\begin{array}{l}\text { Indicator variable equal to } 1 \text { if ISS voting requirement } \\
\text { variable is greater than .01 }\end{array}$ \\
\hline Year & Calendar year of meeting date \\
\hline Industry & 4-digit SIC code \\
\hline
\end{tabular}




\section{B.2 Table 1: Summary Statistics}

Panel A: Full sample

\begin{tabular}{lccccc}
\hline & & & & & Varianc \\
Variable & $\mathrm{N}$ & Mean & Min & Max & e \\
\hline Participation & 158832 & 0.79 & $<.01$ & 1.56 & 0.03 \\
DEFA*non-routine & 158832 & 0.10 & 0.00 & 1.00 & 0.09 \\
Regulation*non-routine & 158832 & 0.52 & 0.00 & 1.00 & 0.25 \\
Ln(Total Assets)*non-routine & 158832 & 3.74 & -1.74 & 14.70 & 15.02 \\
Ln(Market Value*non-routine & 158832 & 3.73 & -1.61 & 13.35 & 14.82 \\
Delta EPS*non-routine & 158832 & 0.04 & -9.27 & 7.69 & 1.99 \\
Auditor Ratification & 158832 & 0.12 & 0.00 & 1.00 & 0.11 \\
Annual*non-routine & 158832 & 0.53 & 0.00 & 1.00 & 0.25 \\
Director Election Post 2010 & 158832 & 0.46 & 0.00 & 1.00 & 0.25 \\
Amend Compensation & 158832 & 0.03 & 0.00 & 1.00 & 0.03 \\
How close vote result & 158832 & 0.93 & 0.00 & 1.00 & 0.02 \\
Vote failed & 158832 & 0.02 & 0.00 & 1.00 & 0.02 \\
Approve Compensation & 158832 & 0.01 & 0.00 & 1.00 & 0.01 \\
Merger & 158832 & $<.01$ & 0.00 & 1.00 & $<.01$ \\
Director Election & 158832 & 0.71 & 0.00 & 1.00 & 0.21
\end{tabular}

Panel B: Routine for 2005-2009

\begin{tabular}{lccccc}
\hline Variable & & & & & Varianc \\
& $\mathrm{N}$ & Mean & Min & Max & e \\
\hline Management For & 44126 & 0.94 & 0.00 & 1.00 & 0.011 \\
Participation & 44126 & 0.88 & $<0.01$ & 1.00 & 0.011 \\
Regulation & 44126 & 0.37 & 0.00 & 1.00 & 0.234 \\
DEFA & 44126 & 0.04 & 0.00 & 1.00 & 0.036 \\
Ln(Outstanding) & 44126 & 18.11 & 7.85 & 23.23 & 1.814 \\
Ln(Total assets) & 44126 & 7.23 & 1.88 & 14.45 & 3.222 \\
Delta EPS & 44126 & -0.13 & -9.27 & 7.69 & 4.589 \\
Special meeting & 44126 & 0.01 & 0 & 1 & 0.01 \\
Ln(Acquisition) & 44126 & 0.02 & -5.52 & 8.18 & 0.108
\end{tabular}


Panel C: Non-routine for 2005-2009

\begin{tabular}{lccccc}
\hline Variable & & & & & Varianc \\
& $\mathrm{N}$ & Mean & Min & Max & $\mathrm{e}$ \\
\hline Management For & 3255 & 0.78 & 0.03 & 1.00 & 0.04 \\
Participation & 3255 & 0.77 & 0.11 & 1.00 & 0.01 \\
Regulation & 3255 & 0.42 & 0.00 & 1.00 & 0.24 \\
DEFA & 3255 & 0.04 & 0.00 & 1.00 & 0.04 \\
Ln(Outstanding) & 3255 & 18.94 & 14.97 & 23.09 & 2.89 \\
Ln(Total assets) & 3255 & 8.31 & 2.34 & 14.45 & 4.74 \\
Delta EPS & 3255 & -0.11 & -9.27 & 7.69 & 6.21 \\
Special meeting & 3255 & 0.01 & 0.00 & 1.00 & 0.01 \\
Ln(Acquisition) & 3255 & 0.01 & -5.52 & 8.18 & 0.19
\end{tabular}

Panel D: 2010-2015

\begin{tabular}{lccccc}
\hline Variable & & & & \multicolumn{2}{c}{ Varianc } \\
\hline Postal Mail & 147225 & 0.69 & 0.00 & 1.00 & 0.21 \\
Special election & 147225 & 0.01 & 0.00 & 1.00 & 0.01 \\
Proxy contest & 147225 & 0.01 & 0.00 & 1.00 & 0.01 \\
Vote fail & 147225 & 0.02 & 0.00 & 1.00 & 0.02 \\
Close management vote & 147225 & 0.03 & 0.00 & 1.00 & 0.03 \\
Ln(Total Assets) & 147225 & 7.08 & -1.78 & 14.76 & 5.54 \\
Delta EPS & 147225 & -0.01 & -9.27 & 7.69 & 2.38 \\
Ln(Outstanding) & 147225 & 17.85 & 11.51 & 24.30 & 2.34 \\
Ln(Market value) & 147225 & 6.77 & -5.17 & 13.35 & 5.27
\end{tabular}


B.2 Table 1, Continued

Panel E: Director Elections

\begin{tabular}{lccccc}
\hline Variable & $\mathrm{N}$ & Mean & Min & Max & Variance \\
\hline & & & & & \\
Management For & 37051 & 0.96 & 0.20 & 1 & 0.00 \\
DEFA & 37051 & 0.38 & 0 & 1 & 0.24 \\
Ln(Total Asset) & 37051 & 8.63 & 4.05 & 14.76 & 3.00 \\
EBITDA & 37051 & 1870.25 & -73.43 & 11967 & 8793397 \\
E Index & 37051 & 4.08 & 2 & 6 & 0.66 \\
Abnormal CEO Comp. & 37051 & 1660.17 & -4877 & 25838 & 35100000 \\
Majority voting & 37051 & 0.55 & 0 & 1 & 0.25 \\
Board size & 37051 & 10.16 & 3 & 34 & 5.91 \\
Percent Independent & 37051 & 8.31 & 0 & 27 & 5.37 \\
Board Holdings & 37051 & 6.09 & 0 & 194.23 & 275.83
\end{tabular}

Panel F: Canadian Table

\begin{tabular}{|c|c|c|c|c|c|}
\hline Variable & $\mathrm{N}$ & Mean & Min & Max & Variance \\
\hline Participation & 1279 & 0.52 & $<.01$ & 1 & 0.04 \\
\hline Routine & 1279 & 0.95 & 0 & 1 & 0.05 \\
\hline $\begin{array}{l}\text { Beneficial Investor } \\
\text { Notice and Access }\end{array}$ & 1279 & 0.28 & 0 & 1 & 0.20 \\
\hline Notice and Access & 1279 & 0.50 & 0 & 2 & 0.69 \\
\hline Special election & 1279 & 0.00 & 0 & 1 & 0.00 \\
\hline Year & 1279 & 2015 & 2014 & 2016 & 0.69 \\
\hline Ln(Total Assets) & 1279 & 5.77 & 0.90 & 9.71 & 3.92 \\
\hline Delta EPS & 1279 & -0.15 & -5.48 & 3.44 & 1.06 \\
\hline Ln(Outstanding Shares) & 1279 & 18.46 & 15.93 & 21.90 & 1.35 \\
\hline Ln(Market Value) & 1279 & 5.28 & 0.40 & 9.70 & 3.76 \\
\hline Director elections & 1279 & 0.79 & 0 & 1 & 0.17 \\
\hline Merger & 1279 & 0.00 & 0 & 1 & $<.01$ \\
\hline
\end{tabular}


B.2 Table 1, Continued

Panel G: Canadian Table 6

\begin{tabular}{lccccc}
\hline Variable & N & Mean & Min & Max & Variance \\
\hline Postal Mail & 5433 & 0.74 & 0 & 1 & 0.19 \\
Notice and Access & 5433 & 0.44 & 0 & 2 & 0.60 \\
Special election & 5433 & 0.01 & 0 & 1 & 0.01 \\
Proxy contest & 5433 & 0.00 & 0 & 1 & 0.00 \\
Vote fail & 5433 & 0.01 & 0 & 1 & 0.01 \\
Close management vote & 5433 & 0.02 & 0 & 1 & 0.02 \\
Year & 5433 & 2015 & 2014 & 2016 & 0.67 \\
Ln(Outstanding) & 5433 & 17.76 & -3.51 & 21.90 & 2.87 \\
Ln(Total Assets) & 5433 & 5.96 & -3.86 & 11.26 & 4.59 \\
Delta EPS & 5433 & -0.26 & -76.65 & 47.55 & 10.81 \\
Ln(Market value) & 5433 & 5.57 & -1.10 & 11.08 & 4.53 \\
\hline
\end{tabular}




\section{B.3 Table 2: Total Non-Participation}

Panel A: Full Sample

(1)

Participation as

Dependent Variable

Non-routine $\quad-0.135^{* * *}$

$(-83.07)$

\begin{tabular}{lc} 
Meeting Fixed Effects & Yes \\
\hline Observations & 251,372 \\
R-squared & 0.882 \\
\hline
\end{tabular}

Notes: This regression estimates total beneficial shareholder non-participation in shareholder meetings by measuring the average difference between routine and non-routine votes within the same shareholder meeting. The amount of non-participation is equal to the decrease in participation during a non-routine vote. Non-routine is an indicator variable for whether broker non-votes were recorded for the vote. The coefficient estimate from this regression is used to interpret the results from Table 3 . The regression includes the entire sample from 2005-2015. Inference is based on the t-statistic, reported in parentheses. Statistical significance level below $1 \%, 5 \%$, and $10 \%$ is denoted by $* * *, * *$, and $*$ respectively.

Panel B: Non-Participation for Russell 3000

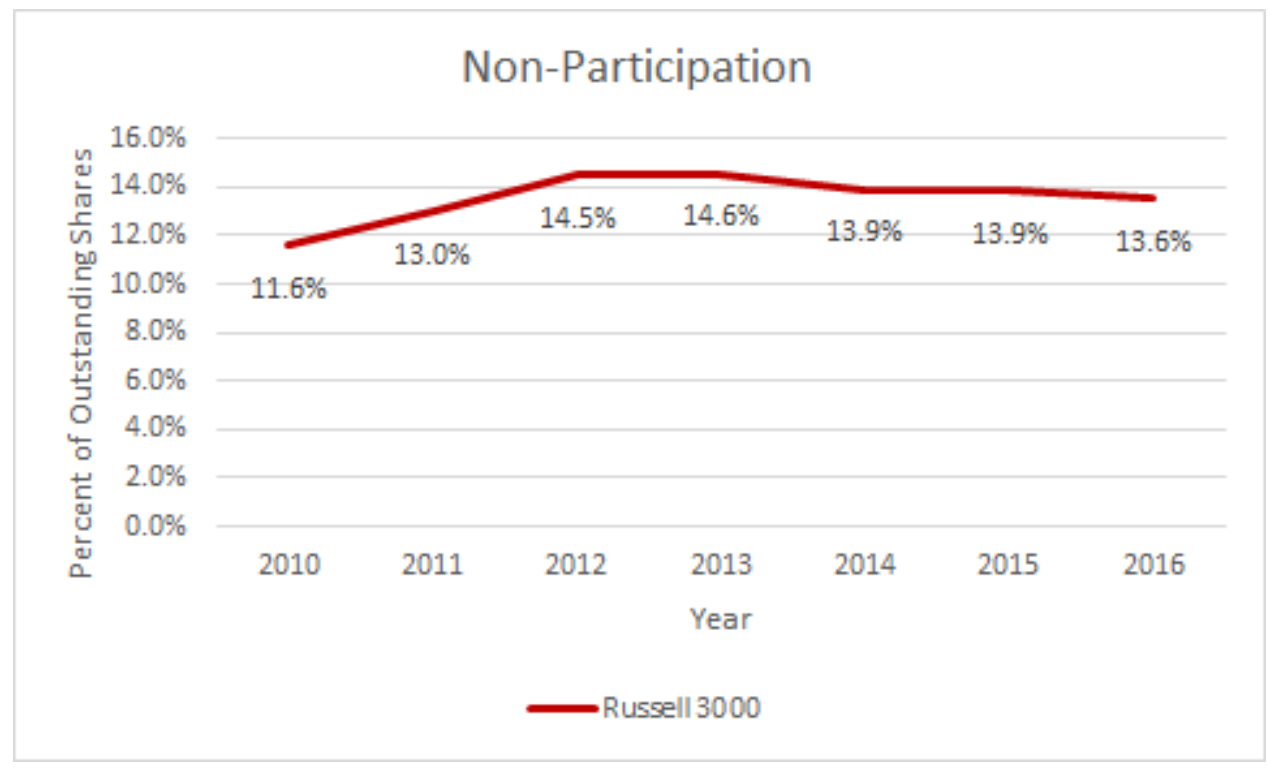

Notes: This graph shows the average broker non-votes divided by outstanding shares for non-routine votes during a calendar year, which provides consistent estimates with the yearly regressions from Panel A. The amount of non-participation is equal to the decrease in participation during a non-routine vote. The sample shows the entire ISS Russell 3000 sample for the years 2010-2016. 


\section{B.3 Table 2, Continued}

Panel C: Retail Participation Partitioned by Total Assets of the Company

\begin{tabular}{lcccrr}
\hline $\begin{array}{l}\text { Quintiles of } \\
\text { Total Assets }\end{array}$ & $\begin{array}{l}\text { Mean (Total } \\
\text { Participation) }\end{array}$ & $\begin{array}{l}\text { Mean } \\
\text { (Individual } \\
\text { Participation) }\end{array}$ & $\begin{array}{l}\text { Mean } \\
\text { (Institutional } \\
\text { Ownership) }\end{array}$ & $\begin{array}{l}\text { Mean (Total } \\
\text { Assets in } \\
\text { Millions) }\end{array}$ & Observations \\
\hline 1 & $60.7 \%$ & $49.8 \%$ & $39.0 \%$ & $\$ 139.33$ & 20,852 \\
2 & $74.9 \%$ & $33.8 \%$ & $58.7 \%$ & $\$ 783.28$ & 20,960 \\
3 & $77.8 \%$ & $32.5 \%$ & $67.9 \%$ & $\$ 2,417.51$ & 20,954 \\
4 & $77.5 \%$ & $55.0 \%$ & $69.3 \%$ & $\$ 7,028.41$ & 20,906 \\
5 & $74.5 \%$ & $59.7 \%$ & $66.0 \%$ & $\$ 104,451.87$ & 20,946 \\
\hline
\end{tabular}

Notes: This table presents the total participation rate and total individual participation (retail and inside investors) partitioned into five quintiles for the 2011-2015 sample matched with Thompson Reuter's institutional ownership data. Individual participation is calculated as $1-\left(\frac{\text { Broker non-votes }}{(1-\text { institutional ownership })}\right)$ for non-routine votes in the sample. The mean total assets in millions and the number of observations (number of ballot items) are also provided. Because observations where Thompson Reuter's had reported more than one hundred percent ownership were excluded, there is a slight imbalance to the number of observations within the quintiles.

\section{Panel D: Retail Participation Partitioned by Number of Short Positions}

\begin{tabular}{lcccrr}
\hline $\begin{array}{l}\text { Quintiles of } \\
\text { Short } \\
\text { Positions }\end{array}$ & $\begin{array}{l}\text { Mean (Total } \\
\text { Participation }\end{array}$ & $\begin{array}{l}\text { Mean } \\
\text { (Individual } \\
\text { Participation) }\end{array}$ & $\begin{array}{l}\text { Mean } \\
\text { (Institutional } \\
\text { Ownership) }\end{array}$ & $\begin{array}{l}\text { Mean (Short } \\
\text { Positions) }\end{array}$ & Observations \\
\hline 1 & $66.3 \%$ & $62.2 \%$ & $38.8 \%$ & 76,586 & 20,393 \\
2 & $75.9 \%$ & $63.8 \%$ & $61.3 \%$ & 783,792 & 20,391 \\
3 & $77.6 \%$ & $51.6 \%$ & $69.8 \%$ & $2,324,115$ & 20,397 \\
4 & $76.1 \%$ & $33.9 \%$ & $69.6 \%$ & $5,302,901$ & 20,385 \\
5 & $71.8 \%$ & $16.0 \%$ & $67.6 \%$ & $21,966,797$ & 20,391 \\
\hline
\end{tabular}

Notes: This table presents the total participation rate and total individual participation (retail and inside investors) sample matched with Thompson Reuter's institutional ownership data partitioned into five quintiles by COMPUSTAT Short position data for the 2011-2015. Individual participation is calculated as $1-\left(\frac{\text { Broker non-votes }}{(1-\text { institutional ownership })}\right)$ for non-routine votes in the sample. The mean short positions and the number of observations (number of ballot items) are also provided. The short positions are taken from reported short positions at the end of the month prior to the meeting date. Because observations where Thompson Reuter's had reported more than one hundred percent ownership were excluded, there is a slight imbalance to the number of observations within the quintiles. 


\section{B.4 Table 3: Effect on Participation}

\section{Panel A: U.S. Setting}

\begin{tabular}{|c|c|c|c|c|}
\hline \multirow[b]{2}{*}{ Participation as Dependent Variable } & \multicolumn{2}{|c|}{ Measure of Treatment 1} & \multicolumn{2}{|c|}{ Measure of Treatment 2} \\
\hline & Design 1 & Design 2 & Design 1 & Design 2 \\
\hline Treatment: & & & & \\
\hline Regulation ${ }^{*}$ non-routine & $\begin{array}{c}-0.022^{* *} \\
(-2.24)\end{array}$ & & & \\
\hline Regulation & & $\begin{array}{c}-0.021^{*} \\
(-1.85)\end{array}$ & & \\
\hline$D E F{ }^{*}$ non-routine & & & $\begin{array}{c}-0.010^{* * *} \\
(-3.03)\end{array}$ & \\
\hline$D E F A$ & & & & $\begin{array}{c}-0.021^{* *} \\
(-2.03)\end{array}$ \\
\hline Control Variables: & & & & \\
\hline Ln(Market Value $){ }^{*}$ non-routine & $\begin{array}{c}0.014^{* * *} \\
(7.78)\end{array}$ & & $\begin{array}{c}0.014^{* * *} \\
(7.90)\end{array}$ & \\
\hline Ln(Total Assets)*non-routine & $\begin{array}{c}0.011^{* * *} \\
(5.98)\end{array}$ & & $\begin{array}{c}0.011^{* * * *} \\
(5.95)\end{array}$ & \\
\hline Delta $E P S^{*}$ non-routine & $\begin{array}{c}-0.001^{* *} \\
(-1.98)\end{array}$ & & $\begin{array}{c}-0.001^{* *} \\
(-1.99)\end{array}$ & \\
\hline Annual*non-routine & $\begin{array}{l}0.001 \\
(0.03)\end{array}$ & & $\begin{array}{l}0.001 \\
(0.05)\end{array}$ & \\
\hline How close vote result & $\begin{array}{l}-0.004 \\
(-0.49)\end{array}$ & & $\begin{array}{l}-0.004 \\
(-0.47)\end{array}$ & \\
\hline Vote failed & $\begin{array}{c}-0.062^{* * *} \\
(-8.30)\end{array}$ & & $\begin{array}{c}-0.062^{* * *} \\
(-8.34)\end{array}$ & \\
\hline Merger & $\begin{array}{l}0.002 \\
(0.21)\end{array}$ & & $\begin{array}{c}0.002 \\
(0.20)\end{array}$ & \\
\hline Auditor Ratification Vote & $\begin{array}{c}0.086^{* * * *} \\
(30.68)\end{array}$ & & $\begin{array}{c}0.086^{* * *} \\
(30.67)\end{array}$ & \\
\hline Director Election & $\begin{array}{c}0.075^{* * *} \\
(28.22)\end{array}$ & $\begin{array}{c}0.097^{* * *} \\
(8.70)\end{array}$ & $\begin{array}{c}0.075^{* * *} \\
(28.21)\end{array}$ & $\begin{array}{c}0.096^{* * *} \\
(8.61)\end{array}$ \\
\hline Director Election Post 2010 & $\begin{array}{c}-0.097^{* * *} \\
(-33.97)\end{array}$ & & $\begin{array}{c}-0.097^{* * *} \\
(-33.96)\end{array}$ & \\
\hline Amend Compensation & $\begin{array}{c}-0.015^{* * *} \\
(-9.87)\end{array}$ & & $\begin{array}{c}-0.015^{* * *} \\
(-9.76)\end{array}$ & \\
\hline Approve Compensation & $\begin{array}{c}-0.017^{* * *} \\
(-8.26)\end{array}$ & & $\begin{array}{c}-0.017^{* * *} \\
(-8.24)\end{array}$ & \\
\hline Ln(Total Assets) & & $\begin{array}{l}0.015 \\
(1.50)\end{array}$ & & $\begin{array}{l}0.015 \\
(1.42)\end{array}$ \\
\hline Delta EPS & & $\begin{array}{l}0.001 \\
(0.91)\end{array}$ & & $\begin{array}{l}0.001 \\
(0.91)\end{array}$ \\
\hline Ln(Outstanding shares) & & $\begin{array}{c}-0.049^{* * *} \\
(-2.61)\end{array}$ & & $\begin{array}{c}-0.049^{* * *} \\
(-2.59)\end{array}$ \\
\hline Special meeting & & $\begin{array}{l}-0.035 \\
(-0.60)\end{array}$ & & $\begin{array}{l}-0.035 \\
(-0.60)\end{array}$ \\
\hline Fixed Effects: & & & & \\
\hline Meeting & Yes & No & Yes & No \\
\hline Year*non-routine & Yes & No & Yes & No \\
\hline Firm & Yes & Yes & Yes & Yes \\
\hline Year & Yes & Yes & Yes & Yes \\
\hline
\end{tabular}




\section{B.4 Table 3, Continued}

Observations

158,832

3,813

0.901

0.801

158,832

3,813

R-squared

Notes: This table shows the effect of the SEC's e-proxy regulation on participation in shareholder elections, using the regulation cutoff. The dependent variable is Participation, which is measured as the number of votes voted for + voted against + voted withheld + voted abstain. I have two research designs and two measures of treatment. DEFA refers to whether a notice was published on EDGAR as a DEFA14A form. Regulation refers to whether the firm was subject to the e-proxy regulation. The partitioned difference-in-differences restricts the sample to only non-routine votes and only between years 2005 and 2009, before the definition of non-routine changed. Delta EPS is winsorized at 1\% and $99 \%$. Standard errors are clustered by firm for Design 1 and meeting for Design 2. Inferences are based on tstatistics, reported in parentheses. Statistical significance levels below 1\%, 5\%, and $10 \%$ are denoted by $* * *, * *$, and $*$, respectively. 


\section{B.4, Continued}

Panel B: Canadian Setting

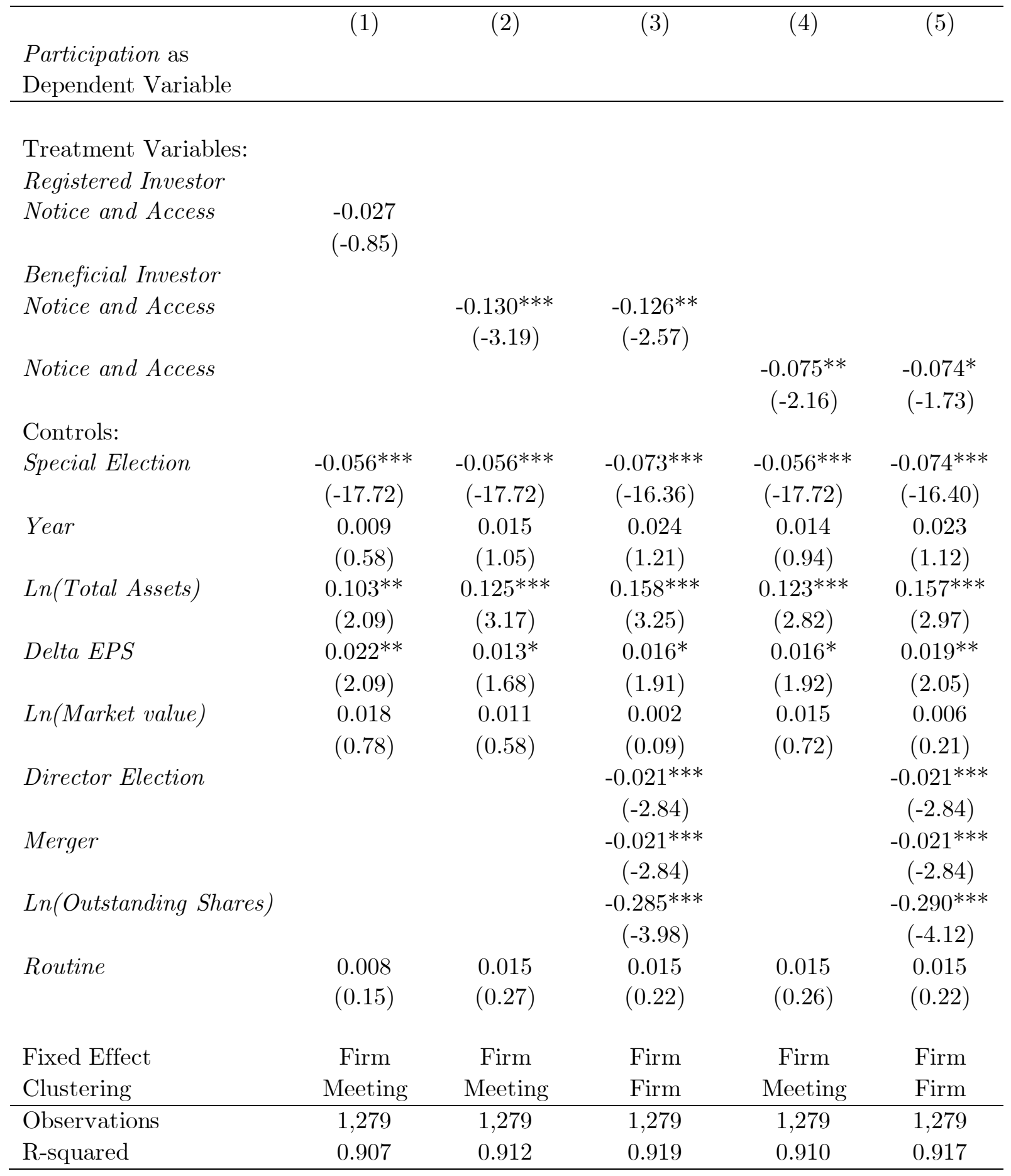

Notes: This table shows the effect that Canada's Notice and Access regulation on participation in shareholder elections, using the regulation cutoff. The dependent variable is Participation, which is measured as the number of votes voted for + voted against + voted abstain. The treatment variables all measure whether the firm choose to use notice and access. Delta EPS is winsorized at $1 \%$ and $99 \%$. 
Standard errors are clustered by meeting or firm. Inferences are based on t-statistics, reported in parentheses. Statistical significance levels below $1 \%, 5 \%$, and $10 \%$ are denoted by $* * *, * *$, and *, respectively. 


\section{B.5 Table 4: Institutional Ownership}

\begin{tabular}{|c|c|c|c|c|c|c|}
\hline $\begin{array}{l}\text { Participation as } \\
\text { Dependent } \\
\text { Variable }\end{array}$ & $\begin{array}{c}1) \\
\text { Lower } \\
\text { Institutional } \\
\text { Ownership } \\
\end{array}$ & $\begin{array}{c}(2) \\
\text { Supermajority } \\
\text { Institutional } \\
\text { Ownership } \\
\end{array}$ & $\begin{array}{c}(3) \\
\text { Difference } \\
\chi^{2} \\
\text { p-value } \\
\end{array}$ & $\begin{array}{c}(4) \\
\text { Lower } \\
\text { Institutional } \\
\text { Ownership } \\
\end{array}$ & $\begin{array}{c}(5) \\
\text { Supermajority } \\
\text { Institutional } \\
\text { Ownership }\end{array}$ & $\begin{array}{c}(6) \\
\text { Difference } \\
\chi^{2} \\
\text { p-value } \\
\end{array}$ \\
\hline \multirow{2}{*}{$\begin{array}{l}\text { Treatment: } \\
\text { Regulation }{ }^{*} \text { non- } \\
\text { routine }\end{array}$} & & & & & & \\
\hline & $\begin{array}{l}-0.043^{* *} \\
(-2.33)\end{array}$ & $\begin{array}{l}-0.012 \\
(-1.05)\end{array}$ & $\begin{array}{l}5.75^{* *} \\
(0.017)\end{array}$ & & & \\
\hline$D E F{ }^{*}$ non-routine & & & & $\begin{array}{c}-0.020^{* * *} \\
(-2.80)\end{array}$ & $\begin{array}{c}-0.012^{* * *} \\
(-3.53)\end{array}$ & $\begin{array}{l}4.32^{* *} \\
(0.038)\end{array}$ \\
\hline $\begin{array}{l}\text { Control Variables: } \\
A T^{*} \text { non-routine }\end{array}$ & $\begin{array}{c}0.020^{* * *} \\
(7.07)\end{array}$ & $\begin{array}{c}0.004^{* *} \\
(2.22)\end{array}$ & & $\begin{array}{c}0.020 * * * \\
(7.05)\end{array}$ & $\begin{array}{c}0.004^{* *} \\
(2.22)\end{array}$ & \\
\hline $\begin{array}{l}\text { Market value*non- } \\
\text { routine }\end{array}$ & $\begin{array}{l}0.004 \\
(1.54)\end{array}$ & $\begin{array}{c}0.014^{* * *} \\
(7.34)\end{array}$ & & $\begin{array}{l}0.005^{*} \\
(1.68)\end{array}$ & $\begin{array}{c}0.015^{* * *} \\
(7.51)\end{array}$ & \\
\hline EPS*non-routine & $\begin{array}{l}-0.001 \\
(-1.08)\end{array}$ & $\begin{array}{l}-0.001 \\
(-1.22)\end{array}$ & & $\begin{array}{l}-0.001 \\
(-1.15)\end{array}$ & $\begin{array}{l}-0.001 \\
(-1.21)\end{array}$ & \\
\hline $\begin{array}{l}\text { Annual }{ }^{*} \text { non- } \\
\text { routine }\end{array}$ & $\begin{array}{l}-0.031 \\
(-1.14)\end{array}$ & $\begin{array}{l}-0.022 \\
(-0.76)\end{array}$ & & $\begin{array}{l}-0.031 \\
(-1.14)\end{array}$ & $\begin{array}{l}-0.021 \\
(-0.74)\end{array}$ & \\
\hline $\begin{array}{l}\text { Director Elect post } \\
2010\end{array}$ & $-0.069^{* * *}$ & $-0.042^{* * *}$ & & $-0.070^{* * *}$ & $-0.042^{* * *}$ & \\
\hline & $(-19.93)$ & $(-19.14)$ & & $(-19.99)$ & $(-19.14)$ & \\
\hline $\begin{array}{l}\text { Amend } \\
\text { compensation }\end{array}$ & $-0.045^{* * *}$ & $-0.029 * * *$ & & $-0.045^{* * *}$ & $-0.029 * * *$ & \\
\hline & $(-13.67)$ & $(-14.40)$ & & $(-13.42)$ & $(-14.36)$ & \\
\hline $\begin{array}{l}\text { How close vote } \\
\text { result }\end{array}$ & $0.026^{*}$ & $\begin{array}{c}0.025^{* *} \\
(2.36)\end{array}$ & & $\begin{array}{l}0.027^{*} \\
(1.84)\end{array}$ & $\begin{array}{c}0.025^{* *} \\
(2.37)\end{array}$ & \\
\hline Vote failed & $\begin{array}{c}-0.067^{* * * *} \\
(-5.00)\end{array}$ & $\begin{array}{c}-0.054^{* * * *} \\
(-5.87)\end{array}$ & & $\begin{array}{c}-0.067^{* * *} \\
(-5.04)\end{array}$ & $\begin{array}{c}-0.054^{* * *} \\
(-5.90)\end{array}$ & \\
\hline $\begin{array}{l}\text { Approve } \\
\text { compensation }\end{array}$ & $-0.058^{* * *}$ & $-0.027^{* * *}$ & & $-0.058^{* * *}$ & $-0.027^{* * *}$ & \\
\hline & $(-13.27)$ & $(-9.83)$ & & $(-13.23)$ & $(-9.82)$ & \\
\hline Merger & $\begin{array}{l}0.010 \\
(1.00)\end{array}$ & $\begin{array}{l}-0.004 \\
(-0.32)\end{array}$ & & $\begin{array}{l}0.009 \\
(0.97)\end{array}$ & $\begin{array}{l}-0.004 \\
(-0.32)\end{array}$ & \\
\hline Director Election & $\begin{array}{c}0.019^{* * *} \\
(8.41)\end{array}$ & $\begin{array}{c}0.010^{* * *} \\
(6.79)\end{array}$ & & $\begin{array}{c}0.019^{* * *} \\
(8.45)\end{array}$ & $\begin{array}{c}0.010^{* * *} \\
(6.81)\end{array}$ & \\
\hline Fixed Effects: & & & & & & \\
\hline Meeting & Yes & Yes & & Yes & Yes & \\
\hline Year*Non-routine & Yes & Yes & & Yes & Yes & \\
\hline Observations & 56,790 & 100,762 & & 56,790 & 100,762 & \\
\hline R-squared & 0.914 & 0.870 & & 0.914 & 0.870 & \\
\hline
\end{tabular}

Notes: This regression shows the splits of the Table 3 results based on institutional ownership.

Supermajority institutional ownership is defined as institutional ownership of more than $66 \%$ of outstanding shares, and lower institutional ownership is institutional ownership of less than $66 \%$ of outstanding shares. The dependent variable for all columns is participation. I have two measures of treatment. DEFA refers to whether a notice was published on EDGAR as a DEFA14A form. Regulation 
refers to whether the firm was subject to the e-proxy regulation. Standard errors are clustered by firm. Inferences are based on t-statistics, reported in parentheses. The statistical difference between tests was calculated using a chi-squared test, with both the chi-squared and p-value reported. Statistical significance levels below $1 \%, 5 \%$, and $10 \%$ are denoted by ${ }^{* * *},{ }^{* *}$, and ${ }^{*}$, respectively. 


\section{B.6 Table 5: Voting Outcomes}

Panel A: Before Dodd-Frank, All Issues, U.S.

(1) (2)

$(3)$

(4)

$\%$ in Agreement with

Management Routine Routine Non-routine Non-routine

Recommendation as

Dependent Variable

Treatment:

$D E F A$

$0.016^{*}$

0.007

(1.68)

$(0.30)$

Regulation

$0.011^{* *}$

$-0.015$

$(2.33)$

$(-0.92)$

Control Variables:

\begin{tabular}{lcccc} 
Ln(Outstanding) & $-0.015^{* * *}$ & $-0.015^{* * *}$ & -0.025 & -0.026 \\
Ln(Total assets) & $(-3.19)$ & $(-3.21)$ & $(-1.27)$ & $(-1.35)$ \\
& 0.007 & 0.007 & 0.014 & 0.014 \\
Delta EPS & $(1.61)$ & $(1.48)$ & $(0.65)$ & $(0.66)$ \\
& -0.000 & -0.000 & -0.000 & -0.000 \\
Special meeting & $(-0.70)$ & $(-0.68)$ & $(-0.03)$ & $(-0.07)$ \\
& $-0.129^{* * *}$ & $-0.128^{* * *}$ & -0.056 & -0.057 \\
Ln(Acquisition) & $(-8.77)$ & $(-8.75)$ & $(-1.47)$ & $(-1.46)$ \\
& 0.002 & 0.002 & 0.003 & 0.003 \\
Fixed Effects: & $(0.70)$ & $(0.79)$ & $(0.29)$ & $(0.28)$ \\
Firm & & & & Yes \\
Year & Yes & Yes & Yes & Yes \\
\hline Observations & Yes & Yes & Yes & 3,255 \\
R-squared & 44,126 & 44,126 & 3,255 & 0.456 \\
\hline
\end{tabular}

Notes: This tests for the effect of the SEC's e-proxy regulation on the percentage of the vote in agreement with management recommendations. The first column shows my measure for adoption based on SEC filings of DEFA14A forms. The second column shows my measure of regulation. Columns three and four are a falsification test that shows the result does not hold with non-routine votes, no exchange of decisionmaking power occurs. Inferences are based on t-statistics, reported in parentheses. Statistical significance levels below $1 \%, 5 \%$, and $10 \%$ are denoted by ${ }^{* * *},{ }^{* *}$, and ${ }^{*}$, respectively. 
Panel B: Uncontested Director Elections, U.S. (B.6 Table 5 continued)

$$
\begin{array}{lllll}
(1) & (2) & (3) & (4)
\end{array}
$$

$\%$ in Agreement Design 2 Cai et al. Design 2 Cai et al. Cai et al. Cai et al. with Management Pre-2010 Pre-2010 2010- 2010-

Recommendation $2015 \quad 2015$

as Dependent

Variable

\begin{tabular}{|c|c|c|c|c|c|c|}
\hline$D E F A$ & $\begin{array}{l}0.010^{*} \\
(1.84)\end{array}$ & $\begin{array}{l}-0.007 \\
(-1.20)\end{array}$ & $\begin{array}{l}0.005^{*} \\
(1.85)\end{array}$ & $\begin{array}{c}-0.011^{* *} \\
(-2.01)\end{array}$ & $\begin{array}{c}-0.012^{* *} \\
(-2.54)\end{array}$ & $\begin{array}{l}-0.004 \\
(-1.06)\end{array}$ \\
\hline Ln(Total Assets) & $\begin{array}{l}0.009^{*} \\
(1.84)\end{array}$ & $\begin{array}{c}-0.010^{* * *} \\
(-2.61)\end{array}$ & $\begin{array}{l}0.002 \\
(0.68)\end{array}$ & $\begin{array}{l}-0.002 \\
(-0.48)\end{array}$ & $\begin{array}{l}-0.004 \\
(-0.94)\end{array}$ & $\begin{array}{l}0.011 \\
(1.46)\end{array}$ \\
\hline Delta EPS & $\begin{array}{l}0.000 \\
(0.54)\end{array}$ & & $\begin{array}{l}0.000 \\
(0.35)\end{array}$ & & & \\
\hline Ln(Outstanding) & $\begin{array}{c}-0.015^{* * *} \\
(-3.15)\end{array}$ & & $\begin{array}{l}-0.002 \\
(-0.43)\end{array}$ & & & \\
\hline Ln(Acquisition) & $\begin{array}{l}0.001 \\
(0.54)\end{array}$ & & $\begin{array}{l}0.001 \\
(0.59)\end{array}$ & & & \\
\hline EBITDA & & $\begin{array}{l}0.000 \\
(1.05)\end{array}$ & & $\begin{array}{c}-0.000^{* * *} \\
(-3.65)\end{array}$ & $\begin{array}{c}-0.000^{* * *} \\
(-2.87)\end{array}$ & $\begin{array}{l}-0.000 \\
(-0.60)\end{array}$ \\
\hline E Index & & $\begin{array}{c}-0.006^{* *} \\
(-2.24)\end{array}$ & & $\begin{array}{l}-0.003 \\
(-0.81)\end{array}$ & $\begin{array}{l}-0.003 \\
(-1.20)\end{array}$ & $\begin{array}{l}-0.002 \\
(-0.89)\end{array}$ \\
\hline $\begin{array}{l}\text { Abnormal CEO } \\
\text { Compensation }\end{array}$ & & 0.000 & & 0.000 & 0.000 & $0.000^{*}$ \\
\hline & & $(0.17)$ & & $(1.09)$ & (1.17) & $(1.89)$ \\
\hline Majority Voting & & $\begin{array}{l}0.002 \\
(0.35)\end{array}$ & & $\begin{array}{l}0.002 \\
(0.39)\end{array}$ & $\begin{array}{l}0.005 \\
(1.07)\end{array}$ & $\begin{array}{l}0.005 \\
(1.02)\end{array}$ \\
\hline Board Size & & $\begin{array}{c}-0.007^{* * *} \\
(-3.20)\end{array}$ & & $\begin{array}{c}-0.013^{* * *} \\
(-3.11)\end{array}$ & $\begin{array}{c}-0.010^{* * *} \\
(-3.49)\end{array}$ & $\begin{array}{l}-0.000 \\
(-0.17)\end{array}$ \\
\hline $\begin{array}{l}\text { Percent } \\
\text { Independent }\end{array}$ & & $0.011^{* * *}$ & & $0.013^{* * *}$ & $0.011^{* * *}$ & 0.003 \\
\hline Board Holdings & & $\begin{array}{c}(3.82) \\
0.001 * * * \\
(2.97)\end{array}$ & & $\begin{array}{c}(3.14) \\
0.001^{* *} \\
(2.46)\end{array}$ & $\begin{array}{c}(3.52) \\
0.001^{* * *} \\
(2.73)\end{array}$ & $\begin{array}{l}(0.92) \\
0.000 \\
(0.74)\end{array}$ \\
\hline
\end{tabular}

Fixed Effects:

\begin{tabular}{lcccccc} 
Firm & Yes & No & Yes & No & No & Yes \\
Industry & No & Yes & No & Yes & Yes & No \\
Year & Yes & Yes & Yes & Yes & Yes & Yes \\
\hline Observations & 36,264 & 12,610 & 54,966 & 37,051 & 49,661 & 49,631 \\
R-squared & 0.362 & 0.231 & 0.445 & 0.363 & 0.340 & 0.581 \\
\hline
\end{tabular}


Notes: This tests for the effect of the SEC's e-proxy regulation on the percentage of the vote in agreement with management recommendations just for uncontested director elections. The first two columns show the period before Dodd-Frank and the NYSE Rule 452 change. The dependent variable is the measure for adoption based on SEC filings of DEFA14A forms. Columns three and four show after Dodd-Frank and the NYSE Rule 452 change, where all uncontested elections are non-routine. Columns five and six show for the entire sample. Standard errors are clustered by firm. Inferences are based on t-statistics, reported in parentheses. Statistical significance levels below $1 \%, 5 \%$, and $10 \%$ are denoted by ${ }^{* * *},{ }^{* *}$, and *, respectively. 


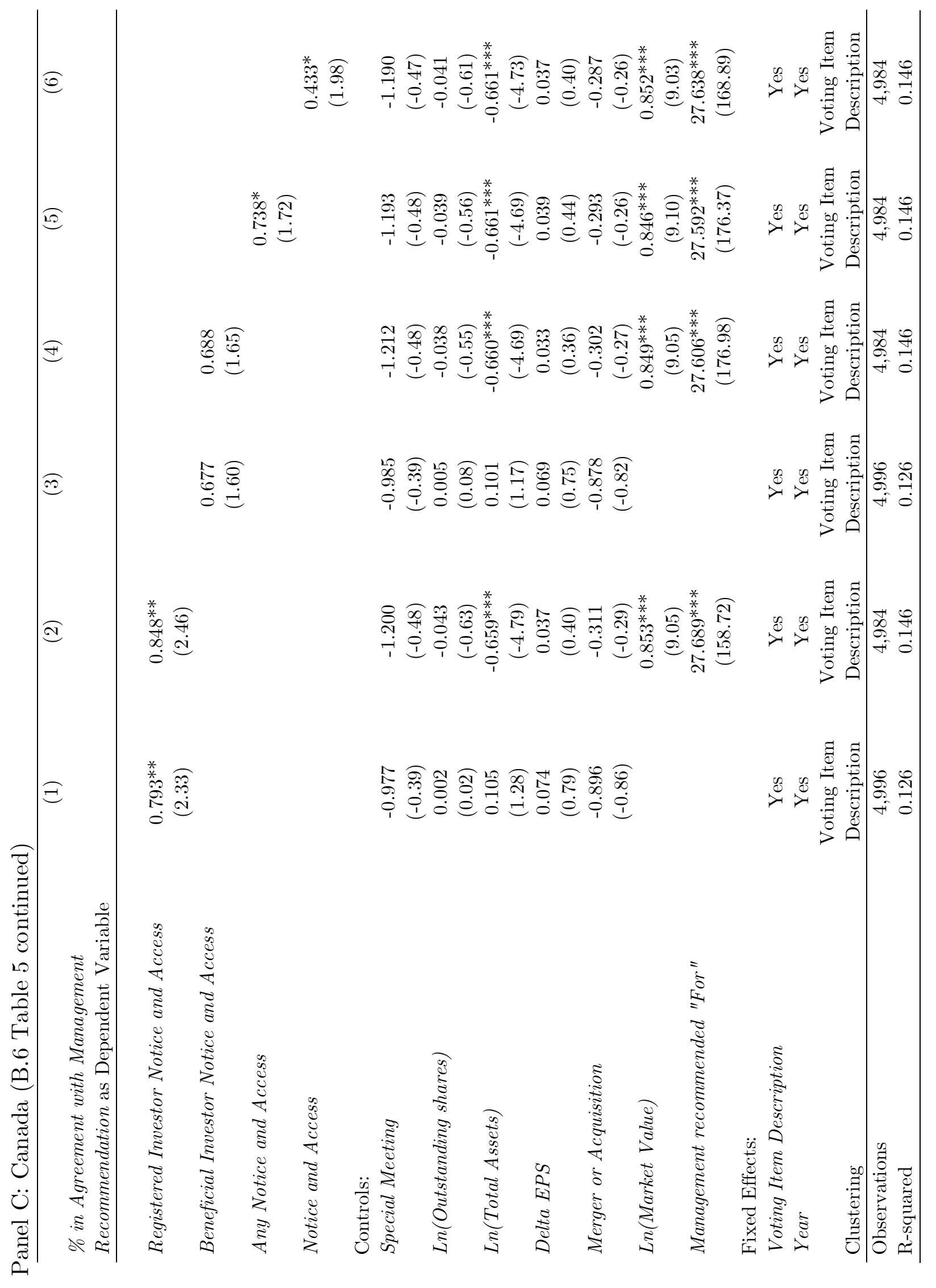




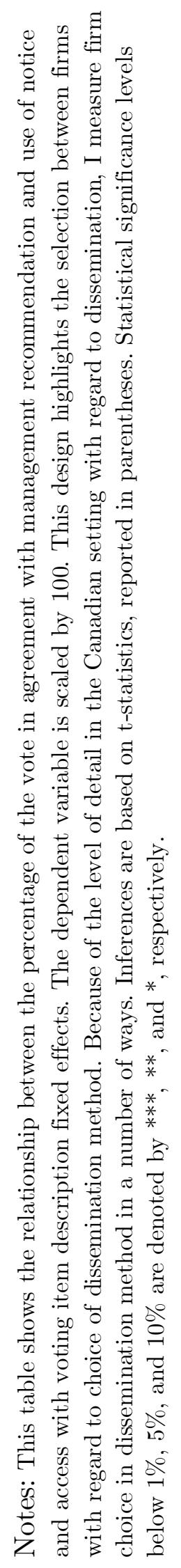


B. 6 Table 5 Continued

Panel D: Canada

$\%$ in Agreement with
(1)
$(2)$
(3)
$(4)$

Management Recommendation

as Dependent Variable

\begin{tabular}{|c|c|c|c|c|}
\hline Notice and Access & $\begin{array}{c}-0.551^{*} \\
(-1.66)\end{array}$ & $\begin{array}{c}-0.551^{* *} \\
(-2.02)\end{array}$ & $\begin{array}{l}-0.384 \\
(-1.14)\end{array}$ & \\
\hline \multicolumn{5}{|l|}{ Registered Investor } \\
\hline Notice and Access & & & & $\begin{array}{l}-0.881 \\
(-1.45)\end{array}$ \\
\hline Special Election & $\begin{array}{c}3.886^{* *} \\
(2.18)\end{array}$ & $\begin{array}{c}3.886^{* *} \\
(2.38)\end{array}$ & $\begin{array}{c}-0.395 \\
(-0.22)\end{array}$ & $\begin{array}{c}3.971^{* *} \\
(2.22)\end{array}$ \\
\hline Ln(Outstanding) & $\begin{array}{l}-0.077 \\
(-0.60)\end{array}$ & $\begin{array}{l}-0.077 \\
(-0.69)\end{array}$ & $\begin{array}{l}-0.095 \\
(-0.72)\end{array}$ & $\begin{array}{l}-0.078 \\
(-0.61)\end{array}$ \\
\hline Ln(Total Assets) & $\begin{array}{l}0.185 \\
(0.17)\end{array}$ & $\begin{array}{l}0.185 \\
(0.23)\end{array}$ & $\begin{array}{l}0.156 \\
(0.14)\end{array}$ & $\begin{array}{l}0.183 \\
(0.17)\end{array}$ \\
\hline Delta EPS & $\begin{array}{c}0.269^{*} \\
(1.68)\end{array}$ & $\begin{array}{c}0.269 * * \\
(2.23)\end{array}$ & $\begin{array}{c}0.270^{*} \\
(1.66)\end{array}$ & $\begin{array}{l}0.258 \\
(1.58)\end{array}$ \\
\hline Merger & $\begin{array}{l}-0.872 \\
(-0.46)\end{array}$ & $\begin{array}{l}-0.872 \\
(-0.55)\end{array}$ & $\begin{array}{l}-1.284 \\
(-0.65)\end{array}$ & $\begin{array}{l}-0.909 \\
(-0.48)\end{array}$ \\
\hline \multicolumn{5}{|l|}{ Management } \\
\hline Recommendation & $\begin{array}{c}40.609^{* * *} \\
(3.18)\end{array}$ & $\begin{array}{c}40.609 * * * \\
(3.30)\end{array}$ & & $\begin{array}{c}40.595^{* * *} \\
(3.18)\end{array}$ \\
\hline Director Election & $\begin{array}{c}5.194^{* * *} \\
(8.34)\end{array}$ & $\begin{array}{c}5.194^{* * *} \\
(8.53)\end{array}$ & & $\begin{array}{c}5.192^{* * *} \\
(8.34)\end{array}$ \\
\hline Auditor Ratify & $\begin{array}{c}7.271^{* * *} \\
(10.50)\end{array}$ & $\begin{array}{c}7.271^{* * *} \\
(10.95)\end{array}$ & & $\begin{array}{c}7.268^{* * *} \\
(10.49)\end{array}$ \\
\hline Sponsor & $\begin{array}{c}25.858^{* *} \\
(2.41)\end{array}$ & $\begin{array}{c}25.858^{* *} \\
(2.52)\end{array}$ & & $\begin{array}{c}25.858^{* *} \\
(2.41)\end{array}$ \\
\hline
\end{tabular}

Fixed Effects:

\begin{tabular}{lcccc} 
Firm & Yes & Yes & Yes & Yes \\
Year & Yes & Yes & Yes & Yes \\
Clustering & Firm & Meeting & Firm & Firm \\
\hline Observations & 4,994 & 4,994 & 4,994 & 4,994 \\
R-squared & 0.367 & 0.367 & 0.298 & 0.367 \\
\hline
\end{tabular}

Notes: This table shows the relationship between the percent of the vote in agreement with management 
and the choice of dissemination method when controlling for firm fixed effects. The dependent variable is scaled by 100. Firm fixed effects and controls for the potential contentiousness of the issue are used to help look at the effect of dissemination reducing selection effects. Inferences are based on t-statistics, reported in parentheses. Statistical significance levels below 1\%, 5\%, and $10 \%$ are denoted by ***, ${ }^{* *}$, and *, respectively. 


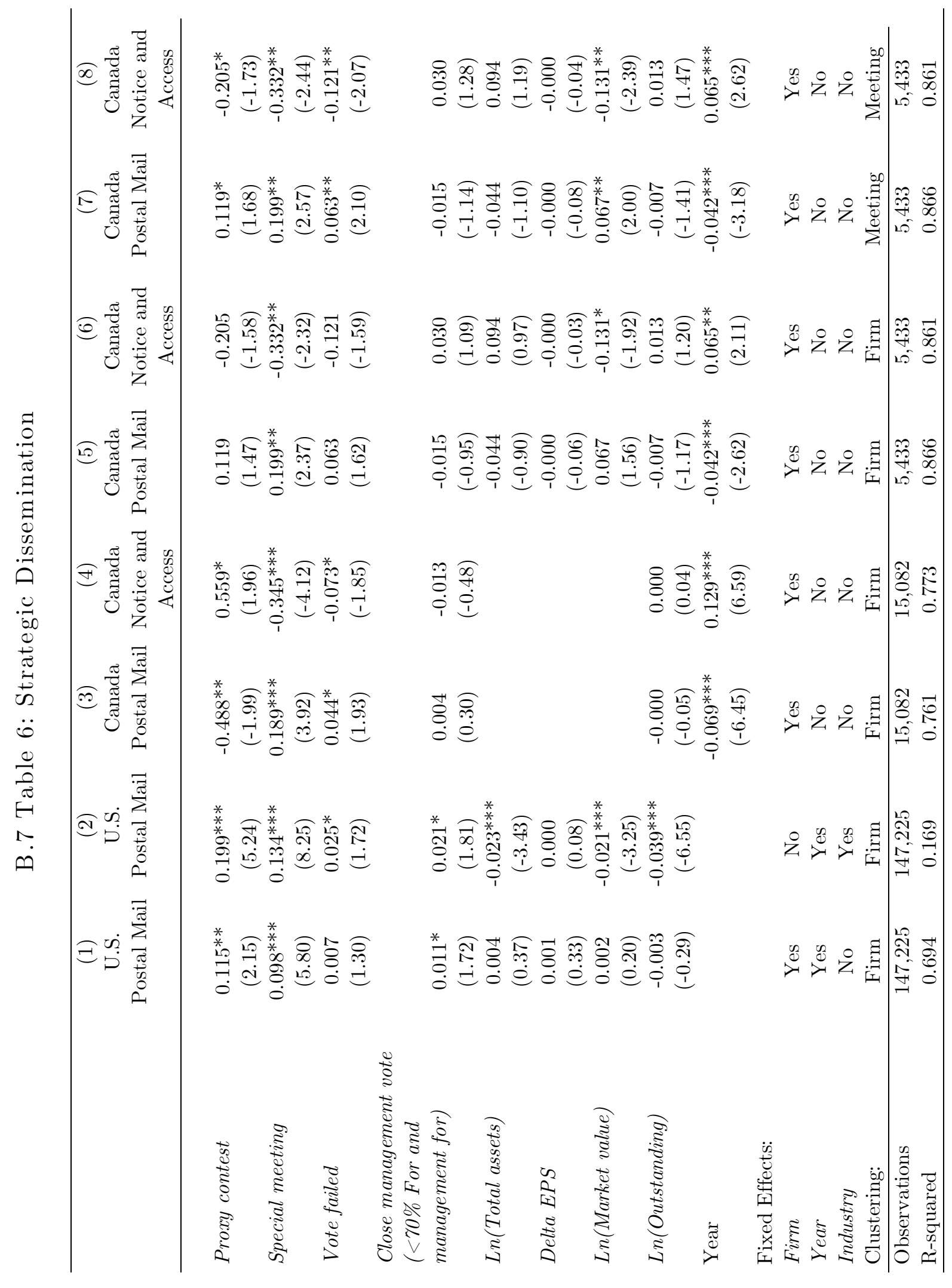




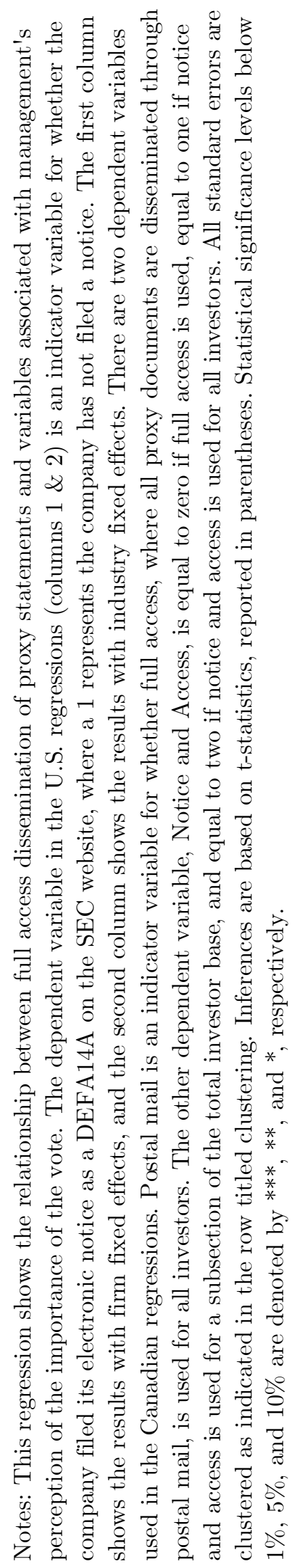




\section{B.8 Table 7: Switching and Stratification}

Panel A: Switching Dissemination

\begin{tabular}{lc}
\hline $\begin{array}{l}\text { Total number of shareholder meetings in U.S. sample } \\
\text { that use different dissemination from previous period }\end{array}$ & $\begin{array}{c}813 \\
(4.4 \% \text { of shareholder meetings in } \\
\text { sample })\end{array}$ \\
\hline $\begin{array}{l}\text { Number of U.S. companies that use multiple } \\
\text { dissemination methods within a year }\end{array}$ & 166 \\
\hline $\begin{array}{l}\text { Total number of shareholder meetings in Canadian } \\
\text { sample that use different dissemination from previous } \\
\text { period }\end{array}$ & 200 \\
\hline
\end{tabular}

Notes: This table shows the number of companies that change dissemination in a single year or between years in the United States and Canada. For the first and second row, a change in dissemination only counts a switch after the company has adopted e-proxy in the US. Therefore, a switch would include returning to hard-copy dissemination and any re-adoption of e-proxy. The U.S. sample extends from 2011 to 2015, and the Canadian sample goes from 2013-2016 and includes only observations where I could match with at least one prior meeting observation.

Panel B: Stratification of Dissemination

\begin{tabular}{lc}
\hline Type of Stratification & Companies \\
\hline Number of Shares & 12 \\
Location of Investor & 6 \\
Type of Investor & 88 \\
Undecided & 5 \\
\hline
\end{tabular}

Notes: This table provides data about the number of firms that use different methods of dissemination for different investors for a single election in Canada, which is called stratification. I decompose these data according to the most common types of stratification criteria as reported in the company's Notice of Meeting and Record Date. Undecided refers to companies that would disclose "To be determined" or "To follow" and then file an amended notice in the week before the election. 111 out of 4325 companies stratify or $2.6 \%$ of the sample. 


\section{B.8 Table 7 Continued}

Panel C: Dissemination by Meeting Type

\begin{tabular}{|c|c|c|c|c|}
\hline Type of Meeting & \multicolumn{2}{|c|}{$\%$ Using Notice and Access } & \multicolumn{2}{|c|}{ Total Number of Observations } \\
\hline Annual & $31.2 \%$ & & 119,426 & \\
\hline Special & $10.1 \%$ & & 1,736 & \\
\hline Proxy Contest & $11.2 \%$ & & 1,148 & \\
\hline Written Consent & $0 \%$ & & 59 & \\
\hline \multicolumn{5}{|l|}{ Canada } \\
\hline Type of Meeting & $\begin{array}{l}\% \text { Using Notice and } \\
\text { Access for Beneficial } \\
\text { Investors }\end{array}$ & \multicolumn{2}{|c|}{$\begin{array}{l}\% \text { Using Notice and } \\
\text { Access for Registered } \\
\text { Investor }\end{array}$} & $\begin{array}{l}\text { Total Number of } \\
\text { Observations }\end{array}$ \\
\hline Annual & $19.1 \%$ & \multicolumn{2}{|c|}{$15 \%$} & 15,560 \\
\hline Annual/Special & $22.3 \%$ & \multicolumn{2}{|l|}{$18.7 \%$} & 14,630 \\
\hline Proxy Contest & $38 \%$ & \multicolumn{2}{|l|}{$8 \%$} & 250 \\
\hline Special & $6.4 \%$ & \multicolumn{2}{|l|}{$5.1 \%$} & 481 \\
\hline
\end{tabular}

Notes: This table presents the percentage of the observations using notice and access and total number of observations. The first 4 rows are from my U.S. sample for the years 2011 through 2015 based on the type of meeting. The type of meeting is based off ISS classification, where Annual/Special elections are included as Special. 


\section{B.9 Table 8: Robustness}

(1) (2)

Dependent Variable $=$ Participation

Fewer Controls

Fewer Controls \& Fewer Fixed Effects Fewest Fixed Effects

Notes: This table shows the effect of the SEC's e-proxy regulation on participation in shareholder elections, using the regulation cutoff. The dependent variable is participation, which is measured as the number of votes voted for + voted against + voted withheld + voted abstain. Regulation refers to whether the firm was subject to the e-proxy regulation. Standard errors are clustered by firm. Inferences are based on t-statistics, reported in parentheses. Statistical significance levels below 1\%,5\%, and $10 \%$ are denoted by $* * *, * *$, and $*$, respectively. 